\title{
FENOMENA PERGESERAN KONFLIK PEMIKIRAN ISLAM DARI TRADISIONALIS VS MODERNIS KE FUNDAMENTALIS vS LIBERALIS
}

\author{
Khoirul Huda*
}

\begin{abstract}
A bstract: A new mode of religious conflict has emerged in Indonesia following the fall of the old regime in the country. The conflict in point is that between the fundamentalists and the liberals, one that means that the nuance of the conflict is no longer organizational any more than it is ideological. We now rarely hear about the conflicts between the traditionalists and the modernists, just as we now rarely are capable of differentiating their basic tenets. The difference between the two has now become to a large extent vague. In the meantime, conflicts are now taking place between the fundamentalists and the liberals on almost regular basis. H ence, we hear the conflict for example between the FUUI and Ulil Abshar Abdalla who received death threat from the afro-mentioned organization. And also the so-called Monas Tragedy, which for some reflects the real tension between the two currents of thought. This paper is designed to analyze this conflictual phenomenon and the implication that may emerge thereof by using the Poststructural theory, which is the continuation of the structuralist theory of Levi-Strauss. What we mean by the Post-structural theory is that which is developed by Michel Foucault (d. 1984) where he speaks of the archeology of knowledge and the genealogy of power. In Foucault's theory, the former is to do with the organization of documents, their classification, their distribution and management in an orderly manner so as to enable us to differentiate between which are relevant and which are not. This theory is also about describing the so-called relations among elements of social phenomena. The latter in the meantime is to do with the analysis of the historical relationship between power and discourse. It concerns with the analysis of the trajectories of a discourse and its practices, and its relationship with what he calls the regime of truth that claims to have the pseudonaturalistic and global implication. This theory deals with the mode of relationship between these two domains. Hence, while this paper is mainly concerned with the religious thought, it is inevitably related to the notion of politics and power.
\end{abstract}

Keyword: the polarization religious thought, conflict, traditionalist, modernist, fundamentalist, liberals

\section{Pendahuluan}

Awal terjadinya skisme umat Islam adalah terbunuhnya 'Uthman bin 'Affan -khalifah ketigapada hari J um'at tanggal 18 Dhural-H ijjah tahun ke - 35 H (656 M) setelah rumahnya dikepung oleh lima ratus penduduk Mesir yang dipimpin oleh 'Udais selama empat puluh tujuh hari. ${ }^{1}$ Peristiwa itu oleh para sejarawan disebut al-fitnah al-kubra 3 juga disebut albab al-maftuh $\beta^{\beta}$ yang berarti terbukanya pintu perang saudara.

Sepeninggal 'Uthman, 'Ali bin A biत्र dib diangkat sebagai khalifah ke-empat. Diangkatnya

* Dosen Tetap Fakultas Tarbiyah Universitas Muhammadiyah Sidoarjo

${ }^{1}$ Abiła'far Muhłmmad bin J arisal-T 'Ilmiyah, 2005).

${ }^{2}$ Nurcholish Madjid, "Skisme dalam Islam : Tinjauan singkat secara kritis-historis terhadap proses dini perpecahan sosial-keagamaan Islam", dalam Kontekstualisasi Doktrin Islam dalam Sejarah, ed. Budhy Munawar-Rachman (J akarta: Yayasan Wakaf Paramadina, 1994), 668.

${ }^{3}$ G.E. B oswort, Dinasti-dinasti Islam ,ter. Ilyas Hasan (Bandung: Mizan, 1993), 24. 
'Ali tidak mampu meredam konflik internal umat Islam. Dengan mengatasnamakan penuntasan pengusutan dalang di balik pembunuh ' $U$ thman, mereka kemudian melakukan pemberontakanpemberontakan di antaranya yang dilakukan 'Aishah, T thah, dan Zubair dalam perang J amal', serta yang dilakukan Mu'awiyah bin Abisufyan -gubernur Shiria- dalam perang Siffir. ${ }^{5}$

Perang siffin, berakhir dengan tahkim (arbitrasi, perwasitan) oleh para juru runding di Adhruh pada bulan J anuari $659 \mathrm{M}$ menghasilkan beberapa kesepakatan antara lain bahwa pembunuhan Uthman tidak dapat dibenarkan dan akan dibentuk lembaga shura untuk pemilihan seorang khalifah yang baru. ${ }^{6}$

Keputusan itu tidak tersampaikan kepada umat Islam saat itu, dan justru yang terjadi adalah pemihakan kepada Mu'awiyah yang mengakibatkan kekecewaan banyak pihak, maka umat Islam saat itu terpecah menjadi empat kelompok yaitu pertama, ahl-shukaratau yang lebih dikenal dengan Khawarij. Kelompok ini awalnya pendukung Ali, tetapi karena 'Ali menerima tawaran Mu'awiyah berdamai dengan cara tahkim maka mereka menyatakan ke luar dan menentang 'Ali sekaligus Mu'awiyah. Kedua, Shi`ah yaitu kelompok yang setia pada 'Ali dan menganggap Ali masih sebagai khalifah yang sah. Bahkan kelompok ini berkeyakinan bahwa 'Ali-lah yang seharusnya sejak awal menggantikan Rasul SAW ketika wafat sebagaimana yang pernah dikatakan beliau di Ghadir Khum. ${ }^{7}$ Ketiga, kelompok Mu'awiyah yaitu mereka yang berasal dari Damaskus yang menganggap Mu'awiyah sebagai khalifah yang sah karena menang dalam diplomasi. Keempat, kelompok moderat atau netral yang menarik diri dari percaturan politik dengan personifikasi $\mathrm{H}$ \$san al-Bastij (64-728). ${ }^{8}$

Sejak munculnya kelompok-kelompok tersebut sampai dengan periode kekhalifahan tinggi (tahun 945) ${ }^{9}$ inilah yang melahirkan diskursus keilmuan Islam sekaligus melahirkan kelompok atau aliran fase pertama yang mengerucut pada empat tradisi keilmuan klasik yaitu ilmu kalam,

\footnotetext{
${ }^{4}$ Tălhăh dan Zubair keduanya adalah sahabat setia Nabi SAW, dan mengangkat sumpah setia kepada 'Ali bin Abi> TAlib, tetapi karena tuntutan keduanya agar 'Ali segera mengadili pembunuh ‘Uthman terabaikan, maka keduanya mencabut sumpah setia kepada 'Ali dan pergi ke Basirah untuk menghimpun kekuatan. Di tengah perjalananan mereka bertemu dengan 'Aishah dan mereka bersepakat untuk melakukan perlawanan kepada 'Ali. Bergabungnya 'Aishah untuk memberontak 'Ali juga dimotivasi oleh a). antara 'Ali dan 'Aishah sudah lama ada pertentangan terutama sejak peristiwa hadithat al-'ifq. b). Pada saat A bußBakr (ayah 'Aishah) diangkat sebagai khalifah, Ali tidak segera melaksanakan bay'iah dan cenderung membangkang c). Ada keinginan dari 'A bd Allah bin Zubair (kemenakan 'Aishah) menjadi khalifah menggantikan 'Uthman. Syalabi, Sejarah dan Kebudayaan Islam (J akata: Pustaka alHusna, 1994), 288.

${ }^{5}$ Latar belakang terjadinya perang Siffin hampir sama dengan perang J amal yaitu Mu'awiyah selalu membakar kemarahan warga dan menuntut 'Ali bin Abi T tib untuk menghukum pembunuh 'Uthmak. Dan karenanya 'Ali memberhentikan Mu'awiyah sebagai gubernur. Tetapi hal itu ditolak, karena penolakan itu 'Ali mengirim 50.000 tentara untuk menumpas pemberontakan Mu'awiyah dan mereka bertemu di lembah Siffin. Ibid, 198.

Ira M. Lapidus, Sejarah Sosial U mmat Islam Bagian Kesatu dan Kedua ter.G hufron A. Mas'adi (J akarta: Rajawali Pers, 1999), 85.

7'Allamah M.H. Thabathaba'I, Islam Syi'ah: Asal-usul dan Perkembangannya, ter. Djohan Effendi (J akarta: Pustaka Utama Grafindo, 1993), 38.

${ }^{8}$ W. Montgomery Watt, Studi Islam Klasik: Wacana Kritik Sejarah ter. Sukoyo et. al (Yogyakarta: Tiara Wacana,1999), 12-99.

${ }^{9}$ Pengunaan periodesasi sejarah Islam di atas berdasarkan skema yang dikembang oleh Marshall G.S. Hodgson. Ia membuat ikhtisar sejarah dunia Islam sebagai berikut: Periode Sasani Akhir dan Khilafah A wal (485-692), Periode Kekhalifahan Tinggi (692-945), Periode Islam Pertengahan A wal (945-1258), Periode Islam Pertengahan Kemudian (1258-1503), Periode Kekaisaran Mesir Serbuk (1503-1789), dan Masa teknis Modern (1789-sekarang). Marshall G.S. Hodgson, The Venture of Islam: Iman dan Sejarah dalam Peradaban Islam, Buku Pertama Lahirnya sebuah Tatanan Baru ter. Mulyadhi Kartanegara (J akarta: Paramadina, 2002), 138-139.
} 
fiqih, filsafat dan tasawuf, ${ }^{10}$ atau dalam terminologi Mohłmmad 'Abid al-J abiriðlisebut sebagai formasi akal Arab yaitu al-'aql al-bayanix(akal retorik) yaitu tumbuh kembangnya ilmu-ilmu bahasa seperti nahwu, balaghah, figh, usjulıfiqh, dan ilmu kalam, al-'aql al-'irfani (akal gnostik) yaitu tumbuh kembangnya filsafat iluminasionisme dan tasawuf, dan al-'aql al-burhanix(akal demonstratif) yaitu tumbuh kembangnya filsafat. ${ }^{11}$ Berikut polarisasi pemikiran Islam fase pertama (dalam perspektif al-J abirił.
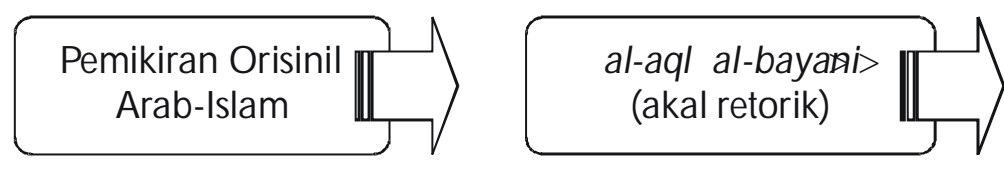

$$
\text { IImu bahasa, Fiqh, IImu kalam }
$$
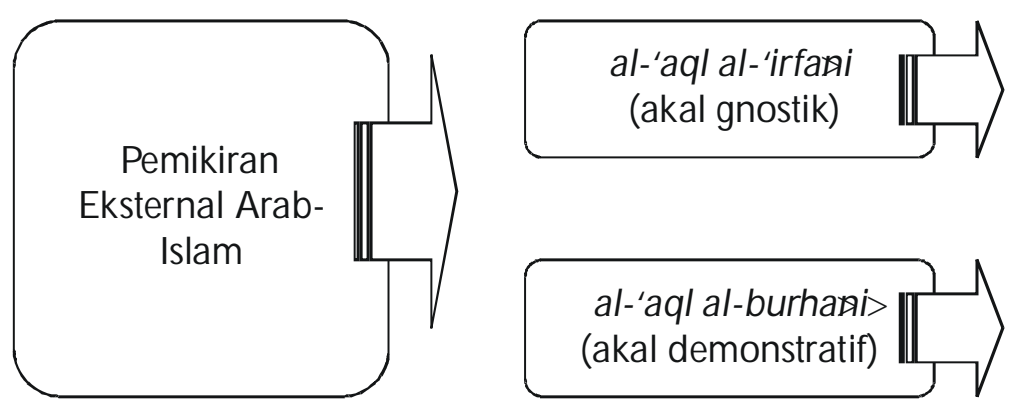

Iluminasionism dan tasauf

Gambar 1 : Polarisasi Pemikiran Islam Fase Pertama

Diskursus keilmuan dan muncul aliran kelompok fase kedua adalah pada periode Islam Pertengahan Kemudian (1258-1503) dan periode Kekaisaran Mesir Serbuk (1503-1789), yaitu diawali dengan runtuhnya kekhalifahan Bani 'Abbasiyah akibat ditaklukkan oleh kerajaan Mongol di bawah pimpinan Hulagu Khan pada tahun 1258 M. ${ }^{12}$

Pada masa ini dunia Islam menampilkan tiga wajah buram yaitu pertama, kehilangan kreatifitas yang ditandai dengan maraknya radisi sharah dan hæhshiyah yaitu aktifitas menafsirkan atau menjelaskan karya-karya ulama terdahulu. ${ }^{13 K}$ edua, kehilangan daya kontrol terhadap akulturasi budaya luar Islam yaitu semakin maraknya adopsi Islam terhadap budaya lokal dan meningkatnya kebutuhan untuk melakukan ritual dan tawasul terhadap orang-orang suci yang dianggap sebagai wali. ${ }^{14}$ Ketiga, menyibukkan diri membangun kesalehan teologis dan menghindar dari dinamika kehidupan antropologis, dengan menyibukkan pada kehidupan kelompok sufi yang membangun jaringan yang disebut dengan tarekat. ${ }^{15}$ Ketiga hal tersebut mengidentifikasikan munculnya gerakan Islam Tradisional.

\footnotetext{
${ }^{10} \mathrm{~N}$ urcholish Madjid, Islam Doktrin dan Peradaban: Sebuah Tela'ah K ritis tentang Masalah Keimanan, Kemanusiaan, dan Kemodernan (J akarta: Yayasan Wakaf Paramadina, 1992), 201-252.

${ }^{11}$ Muhł̧mmad 'Abid al-J abiri>Takwin al-'Aql al-'A rabi ßBeirut: al-M arkazal-Thaqafiæal-'A rabi>1991), 76.

${ }^{12}$ Harun Nasution, Pembaharuan Dalam Islam: Sejarah Pemikiran dan Gerakan (J akarta: Bulan Bintang, 1975), 13.

${ }^{13}$ Nurcholish madjid, "Tradisi Syarah dan Hasiyah dalam Fiqh dan Masalah Stagnasi Pemikiran Hukum Islam", dalam Kontekstualisasi Doktrin Islam dalam Sejarah, Budhy Munawar-Rachman (ed). (Paramadina: J akarta, 1994), 311.

${ }^{14}$ Tentang ziarah ke makam para wali di Dunia Islam seperti Mesir, Sudan, Maroko, Tunisia, Turki, dll, Lihat Henri Chambert-Loir dan Claude Guillot (ed). Ziarah dan Wali di Dunia Islam ter. J ean Couteau et.al (J akarta: Serambi, 2007).

${ }^{15} \mathrm{Di}$ antara tarekat-tarekat yang lahir pada periode ini adalah tarekat Q adiriyah, Sadziliyah, Satariyah, dll. Lihat Sri Mulyati, M engenal dan M emahami Tarekat-tarekat Muktabarah di Indonesia (J akarta: Kencana, 2006).
} 
Kehadiran Islam tradisional direspon oleh beberapa tokoh Islam yang risih dengan perilaku umat Islam yang dianggap semakin menjauh dari nuansa al-Qur'an dan al-Sunnah, di antaranya adalah Ibn Taymiyah dengan membawa jargon kembali kepada al-Qur'an dan al-Sunnah serta membuka kembali pintu ljtihad, la ingin mengembalikan Islam sebagaimana pada masa Nabi SAW dan al-Salaf al-S $\npreceq$ lih. ${ }^{16}$ G erakan yang dilakukan oleh Ibn Taymiyah ini diidentifikasi sebagai Islam Revivalis.

Diskursus keilmuan dan munculnya kelompok atau aliran fase ketiga adalah ketika Islam - terutama di wilayah Turki 'Uthma日i- bersentuhan dengan Barat pada tahun $1700,{ }^{17}$ disusul kemudian dengan kedatangan Napoleon Bonaparte ke Mesir pada tahun 1798 yang membawa perubahan di segala bidang, di antaranya dengan membawa mesin cetak berbahasa Arab yang merupakan rampasan dari Vatikan ke Kairo yang dijadikan sebagai alat propaganda Prancis dengan menggunakan Bahasa Arab, dan diresmikannya academic literaire (akademi sastra) yang dilengkapi dengan perpustakaan menjadikan orang Arab yang pada umumnya menjalani kehidupan yang mandiri, tradisional dan konvensional serta tidak menghiraukan kemajuan dunia luar, secara tiba-tiba tersentak dengan kedatangan bangsa Barat yang membantu mereka terbangun dari tidur panjangnya, dan mengobarkan api intelektual yang membakar semangat umat Islam, sehingga tahun tersebut dijadikan sebagai batasan sejarah pemikiran Arab modern. ${ }^{18}$

Persentuhan antara Islam dan Barat menimbulkan banyak persepsi di kalangan umat Islam yang pada akhirnya melahirkan kelompok-kelompok aliran. Adonis mengidentifikasi -khususnya di wilayah Arab- ada dua kecenderungan yaitu al-thabit, pemikiran yang berdasar pada teks, dan al-mutahăwwil yang dapat dimaknai dengan dua pengertian. Pertama, sebagai pemikiran yang berdasarkan pada teks, namun melalui interpretasi yang membuat teks dapat beradaptasi dengan realitas dan perubahan. Kedua, sebagai pemikiran yang memandang teks tidak mengandung otoritas, dan pemikiran didasarkan pada 'aql dan bukan naql. ${ }^{19}$

Kelompok al-thabit berpandangan bahwa pengetahuan tekstual tidak dapat disejajarkan dengan kriteria apapun di luar dirinya, dan tidak dapat dimajukan di luar pengetahuan dirinya, serta bahasa Arab (sebagai bahasa al-Q ur'an) dan kreatifitasnya tidak dapat disejajarkan dengan kriteria apapun di luar dirinya. Sedangakan kelompok al-mutah đaw wil berpandangan dengan tiga prinsip yaitu kebebasan berkreasi tanpa batas, ketidakberhinggaan pengetahuan dan ketidakberhinggaan eksplorasi, serta kelainan, perbedaan dan pluralitas. ${ }^{20}$

Charles Kurzman mengidentifikasikan ke dalam tiga kelompok tradisi. Pertama, Islam Adat (Customary Islam) yang ditandai oleh kombinasi kebiasaan-kebiasaan atau adat istiadat kedaerahan dan kebiasaan-kebiasaan yang dilakukan di seluruh dunia Islam. Kedua, Islam Revivalis (Revivalist Islam) atau juga disebut Islam Fundamentalis yang mendefinisikan dirinya berbeda dengan Islam Adat dan menyerukan keutamaan Islam pada periode paling awal (al-

\footnotetext{
${ }^{16}$ Ibnu Taimiyah, "Tangga Pencapaian", dalam Khazanah Intelektual Islam, N urcholish madjid (ed). (J akarta: Bulan Bintang, 1985), 247..

${ }^{17}$ Anthony B lack, Pemikiran Politik Islam dari Masa Nabi H ingga Masa Kini ter. Abdullah Ali et al (J akarta: Serambi, 2006), 496.

${ }^{18}$ Philip K. Hitti, H istory of the A rabs, terj. Cecep Lukman Yasin, et.al (J akarta: Serambi Ilmu Semesta, 2005), 954.

${ }^{19}$ Adonis, Arkeologi Sejarah Pemikiran Arab-Islam, Terj. Khairon Nahdiyyin (Yogyakarta: LKIS, 2007), xxvii.

${ }^{20} \mathrm{lbid}, . x x x i v$.
} 
salaf al-şlíh) untuk menegaskan ketidak-absahan praktek-praktek keagamaan masa kini yaitu praktek-praktek yang tidak islami yang berkembang beberapa abad setelah Islam diwahyukan, mengembalikan kemurnian Islam sebagaimana pada masa jaya, menyerang interpretasi adat yang kurang memberi perhatian pada doktrin Islam, membersihkan pusat-pusat strategis tradisi Islam adat. Ketiga, Islam Liberal (Liberal Islam) berpandangan sebagaimana Islam Revivalis terhadap Islam Adat, dengan menghadirkan kembali masa lalu untuk kepentingan modernitas. ${ }^{21}$

Senada dengan Kurzman, A kbar S A hinad mengidentifikasikan terdapatsegitiga kesarjanaan muslim yaitu Tradisionalis, Radikalis, dan Modernis. Kelompok Tradisonalis adalah mereka yang memandang perlunya dialog antara Islam dan Barat karena di antara keduanya terdapat universalime pesan Tuhan dan dialog antar iman. Kelompok Modernis adalah mereka yang menganggap agama tidak lagi sebagai kekuatan atau bimbingan. Sedangkan kelompok Radikalis adalah mereka yang sudah kehilangan kesabaran terhadap Barat dan mengajak untuk melakukan revolusi. ${ }^{22}$

Kelompok-kelompok aliran tersebut terus mengkristalisasi sehingga membentuk peta pemikiran Islam kontemporer ${ }^{23}$ yang dapat diklasifikasikan pada tiga tipologi ${ }^{24}$.

Pertama, tipologi transformatik yaitu para pemikir Arab yang secara radikal mengajukan proses transformasi masyarakat Arab-Muslim dari budaya tradisional-patriarkal kepada masyarakat rasional dan ilmiah. Mereka menolak cara pandang agama dengan kecenderungan mistik dan tidak berdasarkan pada nalar praktis, serta menganggap agama dan tradisi masa lalu sudah tidak relevan lagi dengan tuntutan zaman sekarang, karenanya harus ditinggalkan. ${ }^{25}$

Kedua, tipologi reformistik yaitu para pemikir Arab yang melakukan reformasi dengan mengadakan penafsiran-penafsiran baru yang lebih hidup dan cocok dengan tuntutan zaman. Kelompok ini mempunyai dua kecenderungan yaitu pertama, pemikir yang memakai metode rekonstruktif yaitu melihat tradisi (turath) dengan perspektif pembangunan kembali, yang berarti agar tradisi tetap hidup dandapat diterima, maka ia harus dibangun kembali secara baru dengan kerangka modern dan pra-syarat rasional. Kecenderungan kedua, yang menggunakan metode dekonstruktif yang merupakan fenomena baru pemikir Arab. Para pemikir dekonstruktif dipengaruhi oleh sosiologi mazhab Prancis ${ }^{26}$ terutama gerakan Post-strukturalis dan PostModernisme. ${ }^{27}$

${ }^{21}$ Charles Kurzman, "Pengantar: Islam Liberal dan Konteks Islaminya" dalam Wacana Islam Liberal : Pemikiran Islam Kontemporer tentang Isu-Isu G lobal, ed. Charles Kurzman, Terj. Bahrul Ulum dan H eri J unaidi (J akarta: Paramadina, 2003), xv-xvii.

${ }^{22}$ A kbar S A hined, Posmodernisme: Bahasa dan H arapan Bagi Islam ter. M. Sirozi, (Bandung: Mizan, 1993), 167 176.

${ }^{23}$ Istilah 'kontemporer' merupakan kelanjutan dari modernisasi. Sedangkan batasan Islam kontemporer tidak diketahui secara pasti, namun kebanyakan pemikir Arab sendiri menganggap 'kontemporer' (mu'asiłah) bermula sejak kekalahan A rab oleh Israel tahun 1967, karena kekalahan tersebut merupakan titik yang menentukan dalam sejarah politik dan pemikian Arab modern. Kemal K. Karpat, Political and social in The Contemporary M iddle East(New York:Praeger Publishers, 1982), 13-14.

${ }^{24}$ Issa J. Boullata, Trends and Issues in Contemporery Arab Thougt (Albany: State University of N ew York Press, 1990), 3-4.

${ }^{25} \mathrm{~A}$. Luthfi Assyaukanie, "Tipologi dan Wacana Pemikiran Arab Kontemporer", dalam http:media.isnet.org

${ }^{26}$ Perkembangan sosiologi Prancis diawali dengan munculnya aliran filsafat positivistik yang dimotori -di antaranyaoleh Claude H enri Saint-Simon (1760-1825), Auguste Comte (1798-1875), dan Emile Durkheim (1858-1917). George Ritzer dan Douglas] Goodman, Teori Sosial Modern, 16-20.

${ }^{27}$ A. Luthfi Assyaukanie, "Tipologi 
Ketiga, tipologi ideal-totalistik yaitu kelompok yang hendak menghidupkan kembali Islam sebagai agama, budaya dan peradaban, mereka menolak unsur-unsur asing dari Barat, menyerukan kepada keaslian Islam yang pernah dipraktekkan oleh Nabi dan para khulafa'>alrashidin, dan kembali kepada sumber asli ajaran Islam yaitu al-Qur'an dan al-Sunnah. ${ }^{28}$ Berikut polarisasi pemikiran Islam fase kedua dan ketiga:
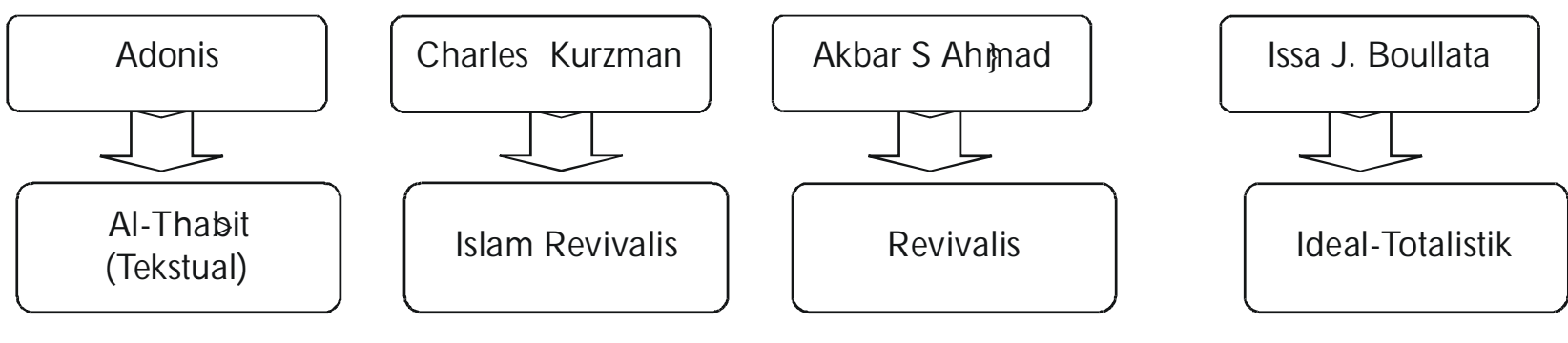

Islam Adat
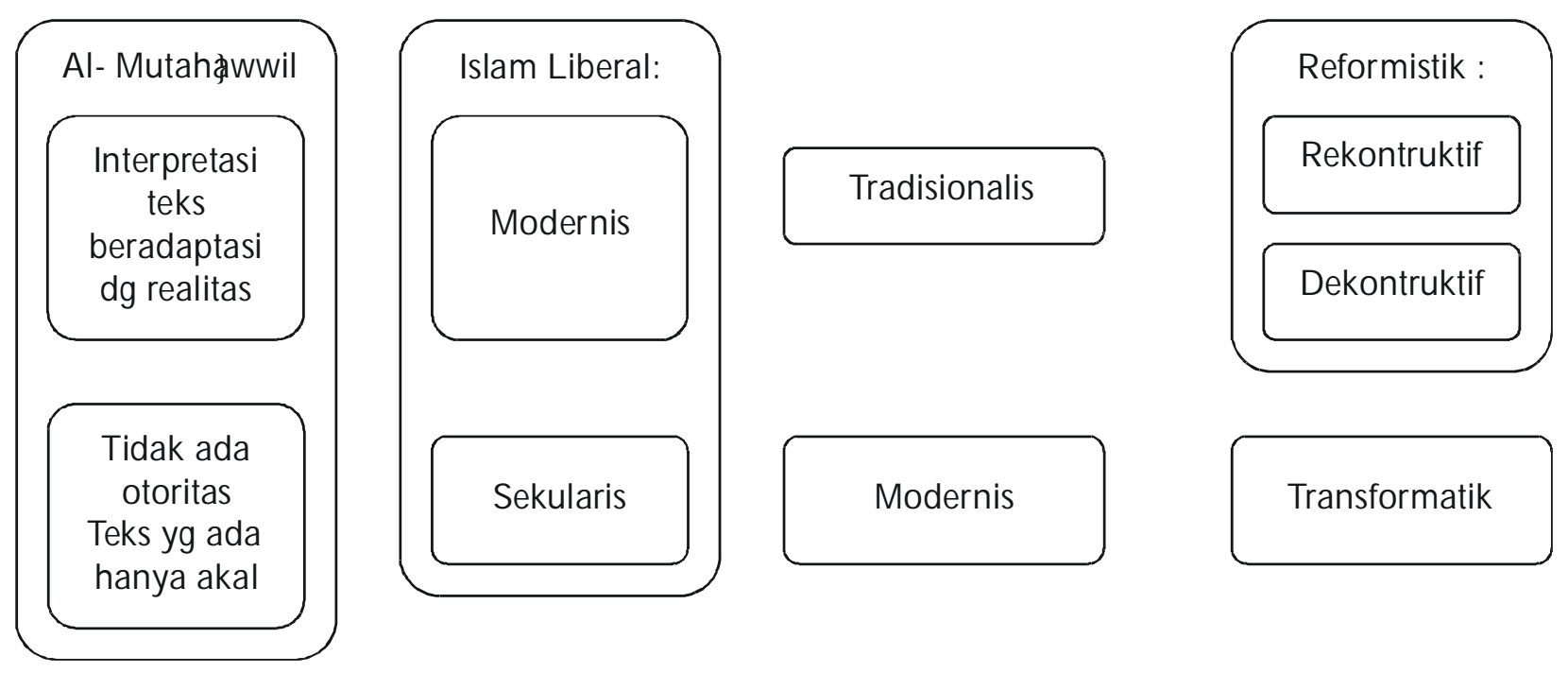

Gambar 2 dan 3 : Polarisasi Pemikiran Islam Fase Kedua

Dari uraian para islamolog di atas, maka dapat disimpulkan bahwa kelompok aliran dalam Islam dapat diklasifikasikan menjadi empat, yaitu:

Pertama, kelompok Islam Tradisionalis yaitu kelompok Islam Adat atau Costumary Islam (menurut istilah Charles Kurzmen). Ciri-ciri kelompok aliran ini adalah kombinasi (sinkretisme) ajaran Islam dengan kebiasaan-kebiasaan atau adat istiadat kedaerahan serta kebiasaan-kebiasaan yang dilakukan di seluruh dunia Islam.

Kedua, kelompok Islam Modernis yaitu kelompok Islam mutah „wwil yang berpandangan bahwa interpretasi teks harus beradaptasi dengan realitas (menurut istilah Adonis), kelompok liberal-modernis (menurut istilah Charles Kurzmen) atau kelompok Islam reformistik (menurut istilah Issa J. Boullata). ${ }^{29}$ Ciri-ciri kelompok aliran ini adalah menggunakan teks dengan ${ }^{28}$ Ibid.

${ }^{29} \mathrm{~B}$ erbeda dengan islamolog lainnya Akbar S. A kmed mendefinisikan 'modernisme' sama dengan 'tradisionalisme' yaitu adalah mereka yang memandang perlunya dialog antara Islam dan Barat karena di antara keduanya terdapat 
interpretasi yang membuat teks dapat beradaptasi dengan realitas dan perubahan, menghadirkan kembali masa lalu untuk kepentingan modernitas, membangun tradisi secara baru dengan kerangka modern dan pra-syarat rasional.

Ketiga, kelompok Islam Liberalis yaitu kelompok Islam mutah„æwwil yang berpandangan bahwa tidak ada otoritas teks, yang ada hanya otoritas akal (menurut istilah Adonis), kelompok Liberal-Sekularis (menurutistilah Charles Kurzmen), atau kelompok Islam Transformatik (menurut istilah Issa J. Boullata). ${ }^{30}$ C iri-ciri kelompok aliran ini adalah kebebasan berkreasi tanpa batas, ketidak-berhinggaan pengetahuan dan ketidak-berhinggaan eksplorasi, serta kelainan, perbedaan dan pluralitas, menolak cara pandang agama dengan kecenderungan mistik dan tidak berdasarkan pada nalar praktis, serta menganggap agama dan tradisi masa lalu sudah tidak relevan lagi dengan tuntutan zaman sekarang, karenanya harus ditinggalkan.

Ke-empat, kelompok Islam Fundamentalis yaitu kelompok Islam al-thabit (menurut istilah Adonis), kelompok Islam Revivalis (menurut istilah Charles Kurzmen dan Akbar S. Akhmad), atau kelompok Islam Ideal-Totalistik (menurut istilah Issa J . B oullata). Ciri-ciri kelompok aliran ini adalah tekstual, menyerukan keutamaan Islam pada periode Nabi dan al-khulafa'‘al-rashidun (al-salaf al-salih), kembali ke sumber pokok Islam (al-Qur'an dan al-Sunnah), dan menolak unsurunsur asing dari Barat. Ke-empat kelompok aliran Islam di Indonesia dapat dipetakan sebagai berikut.

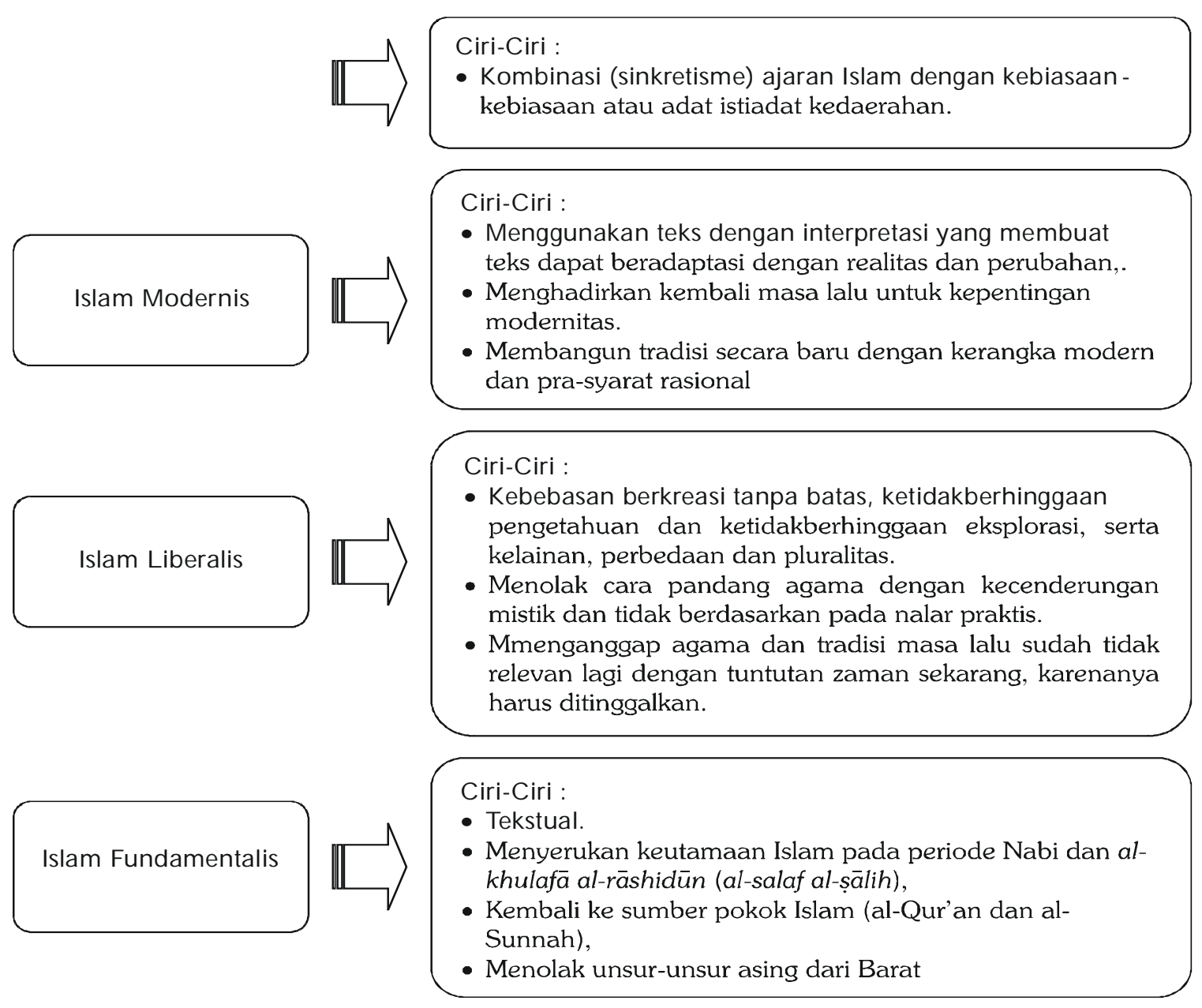

Gambar 3 : Kelompok Aliran Islam di Indonesia 


\section{Islam di Indonesia: Akar Konflik Tradisionalis-Modernis.}

Islam masuk ke nusantara dengan berbagai macam diskursus dan teori. ${ }^{31}$ Meskipun demikian dapat dipastikan bahwa masuknya Islam ke negeri ini ketika peradaban Islam memasuki -meminjam istilah Hodgson- periode Islam pertengahan kemudian (1258-1503) ${ }^{32}$ yang ditandai dengan kemunduran Islam ${ }^{33}$ karena berkembangnya pemikiran tradisionalis, bukan pemikiran rasional. ${ }^{34}$

Dalam bidang keagamaan, nusantara saat itu menjadi mainstream agama Budha yang merupakan agama resmi kerajaan Sriwijaya serta $\mathrm{H}$ indu sebagai agama resmi kerajaan Majapahit (1293-1520) yang baru didirikan oleh Raden Wijaya setelah kejatuhan J ayakatwang akibat serangan tentara Mongol di bawah komando Kubilai Khan. ${ }^{35}$ Pada awal kepemimpinan Raden Wijaya-lah Islam datang (ke wilahah J awa) dibawa oleh Maulana Ibrahim seorang keturunan Zainal Abidin dan sepupu raja Chermen (sebuah negeri di Sabrang), berikutnya oleh Rachmat seorang cucu dari kerajaan Champa dan Maulana Iskak. ${ }^{36}$

Rachmat -kemudian dikenal dengan- Sunan Ampel inilah yang kemudian menjadikan Raden Fatah seorang adipati Glagahwangi yang beribukota Demak yang juga putra Raja Mojopahit B rawijaya $\mathrm{V}$ dengan seorang selir dari Champa mendirikan kerajaan Islam pertama yaitu kerajaan Demak, ketika kekuatan majapahit mulai melemah dan jatuh kekuasaan Demak pada tahun 1527. ${ }^{37}$ Sejak berdirinya kerajaan Demak inilah islamisasi di J awa mulai menjadi sebuah gerakan.

Meskipun demikian, islamisasi di J awa berhadapan dengan dua model kekuatan lingkungan budaya yaitu pertama; kebudayaan petani lapisan bawah yang merupakan bagian terbesar masyarakat yang hidup sederhana dengan religi animisme-dinamisme, kedua; tradisi istana yang merupakan tradisi agung dengan unsur-unsur filsafat Budhisme-Hinduisme ${ }^{38}$. Maka jalan yang ditempuh oleh para penyebar Islam saat itu adalah akulturasi budaya antara Islam dengan budaya

universalime pesan Tuhan dan dialog antar iman. Lihat Akbar S Ahined, Posmodernisme, 167-176.

${ }^{30}$ Akbar S. Ahmed mendefinisikan 'liberalisme' sama dengan 'modernisme' yaitu mereka yang menganggap agama tidak lagi sebagai kekuatan atau bimbingan. Ibid., 167-176.

${ }^{31}$ Terdapat berbagai teori tentang asal penyebaran Islam Indonesia, antara lain: pertama, bahwa Islam masuk ke Indonesia melalui anak benua India (Gujarat dan Malabar) dengan bukti bahwa mayoritas umat Islam di daerah tersebut bermazhab Shafi $\dot{x}$ serta adanya kesamaan bentuk batu nisan pada makam Maulana Malik Ibrahim di Gresik dengan batu nisan yang berada di daerah Cambay Gujarat. Kedua, Islam masuk ke Indonesia melalui Coromandel dan Malabar. Selain karena kesamaan mazhab juga kedua kota tersebut menjadi arus utama perdagangan India-Indonesia. Ketiga, Islam masuk ke Indonesia langsung dari Arabia -terutama- Mesir karena juga adanya kesamaan mazhab. Azyumardi Azra, J aringan Ulama Timur Tengah dan Kepulauan Nusantara Abad XVII XVIII (J akarta: Kencana, 2007), 2-12.

${ }^{32}$ Pengunaan periodesasi sejarah Islam di atas berdasarkan skema yang dikembangkan oleh Marshall G.S. H odgson. la membuat ikhtisar sejarah dunia Islam sebagai berikut: Periode Sasani Akhir dan Khilafah Awal (485-692), Periode Kekhalifahan Tinggi (692-945), Periode Islam Pertengahan Awal (945-1258), Periode Islam Pertengahan Kemudian (1258-1503), Periode Kekaisaran Mesir Serbuk (1503-1789), dan M asa teknis Modern (1789-sekarang). Marshall G.S. Hodgson, The Venture of Islam, 138-139.

${ }^{33} \mathrm{H}$ arun Nasution, Islam ditinjau dari berbagai aspeknya J ilid I (J akarta UI Press, 1985, 79

${ }^{34} \mathrm{H}$ arun Nasution, Islam Rasional: Gagasan dan Pemikiran Prof. Dr. Harun Nasution (Bandung: Mizan, 1995), 7.

${ }^{35}$ D.G.E. Hall, Sejarah Asia Tenggara, ter. IP. Soewarsha (Surabaya: Usaha Nasional, 1988), 76-77.

${ }^{36}$ Thomas Stamford Raffles, The H istory of J ava ,ter. Eko Praseyoningrum et.al (Yogyakarta: Narasi, 2008), 460464.

${ }^{37} \mathrm{~A}$ hmad Khalil, Islam J awa: Sufisme dalam Etika dan Tradisi J awa (Malang: UIN Malang Press, 2008), 61

${ }^{38}$ Ibid., 78-79 
lokal saat itu ( $\mathrm{H}$ indu), ${ }^{39}$ yang menandai berdirinya gerakan Islam Tradisionalis.

Ketika kerajaan-kerajaan Islam mulai berdiri dan berkembang pada abad ke- $16^{40}$ saat itulah datang orang-orang Eropa untuk pertama kalinya. ${ }^{41}$ Pada awalnya kedatangan mereka karena ketertarikan dengan sumber daya alam di Nusantara, tetapi kemudian berkembang untuk menguasai perdagangan. Dan karenanya tidak jarang terjadi konflik antara bangsa Eropa tersebut dengan penguasa lokal, bahkan di antara bangsa Eropa sendiri seperti konflik antara bangsa Portugis, Belanda dan Inggris ketika berebut jalur perdagangan Ambon dan Banda. ${ }^{42}$

Konflik antar bangsa-bangsa Eropa di Nusantara pada akhirnya dimenangkan Belanda yang ditandai semakin kokohnya VOC yang didirikan oleh J an Pieterson Coen tahun 1623 ke seluruh pusat-pusat perdagangan di Nusantara. ${ }^{43}$ Dominasi perdagangan oleh Belanda dan runtuhnya kerajaan-kerajaan di Nusantara menandai awal penjajahan rezim Belanda dengan menerapkan tanam paksa pada tahun $1816,{ }^{44}$ hingga diberlakukannya 'politik etik' yang diresmikan tahun 1901 oleh Ratu Wilhelmina (1890-1948) ketika ia mengumumkan suatu penyelidikan tentang kesejahteraan di J awa. ${ }^{45}$

Kebijakan 'politik etik' pada tahun 1902 ditindaklanjuti oleh Alexander W.F Indenburg Menteri U rusan Daerah J ajahan (1902-1909) yang juga Gubernur J endral B elanda di Indonesia (1909-1916) dengan melaksanakan tiga prinsip yang dianggap sebagai dasar kebijakan baru

\footnotetext{
${ }^{39} \mathrm{~A}$ kulturasi budaya antara Islam dan budaya lokal (Hindu), di antaranya adalah wayang dan teori kesaktian yang oleh Woodward diangap sebagai upaya intelektual (penyebar Islam saat itu) yang sangat pintar dan njlimet untuk mengharmonisasikan dua tradisi keagamaan yang sangat berbeda. Lihat Mark R Woodward, Islam J awa Kesalehan Normatif Versus Kebatinan, ter. Hairus Salim (Yogyakarta: LKIS, 2008), 352.

${ }^{40}$ Diantara kerajaan-kerajaan Islam terbesar di Indonesia saat itu adalah pertama, kerajaan Aceh (wilayah Indonesia bagian Barat) dengan raja pertamanya Ali Mughayat Syah (1514-1530) Portugis pertama kali masuk ke J ohor tahun 1513 selanjutnya ke Aceh. Dan pada tahun 1520 Aceh mengadakan perlawanan kepada Portugis. Kedua, Kerajaan Demak di J awa yang menguasai seluruh J awa dari barat sampai timur. Pada tahun 1523 Sunan G unungjati bersama tentara Demak berangkat ke J awa Barat untuk mendirikan pusat perdagangan di Banten dan pada tahun 1527 terjadi kontak senjata antara tentara Gunungjati dengan Portugis. Ketiga, Kerajaan G owa di Sulawesi Selatan yang berdiri pada tahun 1530. Tahun 1540 Portugis datang ke kerajaan ini untuk missi Kristenisasi dan perdagangan rempah-rempah dan budak, dan VOC mendirikan kantor perdagangan pertama di wilayah ini pada tahun 1609. Lihat M.C. Ricklefs, Sejarah Indonesia Modern 1200-2004, ter. Satrio Wahono. et.al (J akarta: PT. Serambi Ilmu Semesta, 2005), 81-115.

${ }^{41}$ Secara umum bangsa Eropa yang masuk pertama kali ke wilayah Indonesia yang saat itu masih berbentuk kerajaan-kerajaan adalah: Portugis (tahun 1510), B elanda (tahun 1959), Inggris (tahun 1601). Di antara mereka sering terjadi konflik dan peperangan akibat perebutan wilayah dagang. Thomas Stamford Raffles, The History, Xvii-XXV.

${ }^{42}$ D.G.E. Hall, Sejarah, 225.

${ }^{43}$ Ibid., 273

${ }^{44}$ Diterapkannya tanam paksa oleh pemerintah Hindia-B elanda -setelah sekian lama- menimbulkan banyak reaksi. Tidak hanya dari masyarakat Nusantara tetapi juga dari seorang Presiden Batavia Society of Artand Science yang bernama Baron van Hoevel yang dikenal sebagai 'colonial opposition', juga penerbitan buku-buku dan selebaran pada tahun 1860 yang menentang tanam paksa yaitu Max Havelaar yang ditulis oleh Edward Douwes Dekker dengan nama samaran Multatuli, dan selebaran-selebaran Isaac Fransen vander Putte- seorang tokoh liberal yang menentang pemerintah- di antaranya berjudul The Regulation of Sugar Contract in J ava, yang karena perlawanannya itu la oleh Perdana Menteri Belanda - saat itu- Dr. Abraham Keyper yang berhaluan sosialis diangkat sebagai menteri urusan koloni pada tahun 1883-1866.Ibid., 544.

${ }^{45}$ Diresmikannya 'politik etik' oleh Ratu tidak terlepas dari C. Th. Van Deventer seorang ahli hukum yang pernah tinggal di Indonesia (1880-1897) menerbitkan sebuah artikel 'Een eereschuldd' (suatu hutang kehormatan) di dalam jurnal Belanda de Gids pada tahun 1899 yang menyatakan bahwa, "Negeri Belanda berhutang kepada bangsa Indonesia karena semua kekayaan (Belanda) diperas dari Indonesia. Hutang ini sebaiknya dibayar kembali dengan jalan memberi perioritas utama kepada kepentingan rakyat Indonesia di dalam kebijakan colonial". M.C. Ricklefs, Sejarah Indonesia, 320.
} 
tersebut yaitu: pendidikan, pengairan, dan perpindahan penduduk . ${ }^{46}$

Di bidang pendidikan pemerintah Belanda, lebih mengutamakan model pendidikan yang digagas oleh Snouck H urgronje dan J H . A bendanon direktur Pendidikan yang pertama (19001905) yaitu model pendidikan yang bergaya Eropa dengan bahasa Belanda sebagai bahasa pengantar. Pendidikan ini diperuntukkan bagi kaum elit Indonesia yang dapat dipengaruhi Barat, dengan tujuan mereka dapat mengambil alih pekerjaan yang selama ini ditangani orang-orang Belanda sehingga menciptakan elit yang tahu berterima kasih dan bersedia bekerja sama, memperkecil anggaran belanja negara, mengendalikan 'fanatisme' Islam, dan menciptakan keteladanan untuk masyarakat golongan bawah. Pada tahun 1900 tiga hoofdenscholen (sekolah para kepala) di Bandung, Magelang dan Probolinggo diubah menjadi OSVIA yaitu sekolah pelatihan untuk para pejabat pribumi. Pada tahun 1900-1902 sekolah 'dokter-J awa' di Weltevreden diganti menjadi STOVIA yaitu Sekolah Pelatihan Dokter Pribumi ${ }^{47}$. Didirikannya OSVI dan STOVIA inilah yang menjadi benih berdirinya gerakan Indonesia Modern.

Organisasi modern pertama untuk kalangan priyai digagas oleh dr. Wahidin Soedirohusono (1857-1917). Ia adalah lulusan STOVIA dan bekerja sebagai dokter pemerintah Belanda. Ia bersama teman-teman alumni STOVIA seperti dr.Tjipto Mangunkusumo (1885-1943), dr. Radjiman Wediodiningrat (1879-1951) pada bulan Oktober 1908 mendirikan perkumpulan Boedi Oetomo. ${ }^{48}$

Berdirinya Boedi O etomo oleh para lulusan STOVIA menginspirasi lulusan OSVIA untuk membuat organisasi yang sama. Pada tahun 1909 Tirtoadisurjo (1880-1918) mendirikan Serikat Dagang Islamiyah di Batavia dan tahun 1910 di Bogor. la juga menginspirasi lulusan OSVIA yang tinggal di Surakarta Haji Samanhudi (1868-1956), serta H.O.S Tjokroaminoto (1882-1934) lulusan OSVIA yang tinggal di Surabaya untuk membuka cabang SDI di kota-kota tersebut. Pada tahun 1912 Serikat Dagang Islam (SDI) dirubah menjadi Serikat Islam (SI) perubahan nama dimaksud untuk mencerminkan adanya kesadaran umum bahwa anggota-anggotanya yang berkebangsaan Indonesia dan beragama Islam. ${ }^{49}$

Kehadiran Boedi O etomo dan Serekat Islam menginspirasi berdirinya organisasi-organisasi lain yang bukan dari lulusan sekolah Belanda, ${ }^{50}$ tetapi oleh penduduk pribumi atau etnis lain yang memfokuskan pada kegiatan sosial-keagamaan, di antaranya Muhammadiyah di Yogyakarta

${ }^{46}$ Ibid., 320

${ }^{47}$ Ibid., 330

${ }^{48}$ Dr. Wahidin adalah redaktur majalah Retnadhoemilah yang dicetak dengan bahasa J awa dan Melayu. Selain berpendidikan B arat, Wahidin adalah seorang pemain musikJ awa Klasik (gamelan) dan wayang. Dia memandang bahwa kebudayaan J awa terutama diilhami oleh Hindu-Budha dan menjadi merosot karena kedatangan Islam. Dr. Tjipto adalah seorang pemikir radikal. Dia menginginkan Boedi O etomo menjadi partai politik yang berjuang untuk mengangkat rakyat Indonesia pada U mumnya. Dr. Radjiman lebih banyak dipengarhui budaya J awa, dialektika Hegel, subyektifisme Kant, antirasialisme Bergson dan pengikut ajaran Teosofi. Ibid., 343-345.

49 Ibid., 348.

${ }^{50} \mathrm{~A}$ hmad Dahlan - pendiri Muhammadiyah- pada tahun 1909 la bertamu ke Rumah dr. Wahidin Sudirohusodo di Ketandan Yogyakarta. Ia bertanya berbagai hal tentang Budi Utomo dan tujuaannya. Setelah ia mendapatkan jawaban secara lengkap dan secara umum sesuai dengan cita-citanya, maka ia ingin menjadi anggota Boedi Oetomo Cabang Yogyakarta. Di sinilah la belajar organisasi yang disusun secara modern, mempunyai pengurus tetap serta anggota, tujuan, rancangan pekerjaan dan sebagainya. Musthafa Kamal Pasha dan Ahmad Adaby Darban, M uhammadiyah sebagai Gerakan Islam: dalam Perspektif H istoris dan Ideologis (Yogyakarta: LPPI, 2003), 113. 
(tahun 1912), J ama'atul Khair, kemudian al-Irsyad di J akarta terutama untuk etnis Arab (tahun 1914), Thawalib di Sumatera (tahun 1817), dan Persatuan Islam (tahun 1923) yang menjadi representasi gerakan modernis di Indonesia. ${ }^{51}$

Orientasi pergerakan organisasi-organisasi modern tersebut berbeda antara satu dengan yang lain dan tetap saling mendukung. SI -organisasi Islam pertama di Indonesia-berorientasi meningkatkan kemampuan berdagang Muslim Indonesia terutama menghadapi dominasi ekonomi pedagang Cina mempunyai hubungan erat dengan Muhammadiyah sampai sekitar tahun 1920-an. Muhammadiyah dan al-Irsyad, kedua pemimpin organisasi ini -A hmad Dahlan dan Ahmad Surkati- bersepakat merehabilitasi kaum muslimin Indonesia dengan memperbaiki kondisi keagamaan dan sosial-ekonomi. Surkati berkonsentrasi pada komunitas Arab dan Dahlan pada kaum Muslim Indonesia Asli. Persis berorientasi pada bidang sosial yang menitik beratkan pada penyebaran pemurnian ajaran Islam dengan jargon kembali ke al-Qur'an dan al-Sunnah ${ }^{52}$ yang mengharuskan organisasi terlibat dalam debat publik dan berbagai polemik melalui pengajian dan penerbitan. ${ }^{53}$

Kehadiran organisasi-organisasi modernis-terutama SI dan Muhammadiyah-mendapatkan reaksi defensif dari tokoh ulama tradisionalis dan usahawan J awa Timur..$^{54}$ Pada tanggal $31 \mathrm{~J}$ anuari 1926 berkumpul di rumah KH. Wahab Chasbullah (1888-1971) ${ }^{55}$ di Kertopaten Surabaya mereka memikirkan langkah bersama untuk mempertahankan Islam tradisional yang mereka praktekkan selama ini, dan diakhir diskusi itu mereka mendirikan Nahdlatul 'Ulama (NU) ${ }^{56}$ untuk mewakili

\footnotetext{
${ }^{51}$ Dhurorudin Mashad, Akar Konflik Politik Islam di Indonesia (J akarta: Pustaka al-Kautsar, 2008), 4. Identitas modernis dilekatkan pada organisasi-organisasi ini -selain struktur kepengurusan, tujuan dan rencana kerja yang tersusun rapi- juga kemampuan merekonstruksi wacana yang berkembang saat itu. Muhammadiyah - misalnyamemandang bahwa Islam tidak sebatas menjalankan ritual keagamaan (ibadah) semata, tetapi Islam juga harus diterjemahkan ke dalam realitas kehidupan keagamaan, sosial, ekonomi, politk kaum muslimin Indonesia. Achmad J ainuri, Ideologi Kaum Reformis: M elacak Pandangan Keagamaam Muhammadiyah Periode Awal (Surabaya: LPAM, 2002), 5.

${ }^{52}$ G erakan purifikasi Islam diidentifikasi pertama kali oleh Ibn Taymiyah (1263-1328) dan mencapai puncak radikal dan tak kenal kompromi oleh Muhammad bin Abdul Wahab (1702-1792) dengan jargon shirk, tahayyul, bid'ah dan khurafatatas praktek keagamaan yang tidak ada dalam al-Q ur'an dan al-Sunnah. Misalnya Istigathah: Shirk, memakai gelang atau jimat: shirk, mengagungkan orang salih: kufur, Larangan berziarah kubur dll. Lihat Imam 'Abdul Wahhab, Kitab Tauhid, ter. Abdul Q adir et.al. (Bandung: Pustaka, 1987).

${ }^{53} \mathrm{Achmad}$ J ainuri, Ideologi. , 2-3. lihat juga. Syafiq A. Mughni, Hassan Bandung Pemikir Islam Radikal (Surabaya: Bina Ilmu, 1994), 53.

${ }^{54}$ Martin van Bruinessen, NU: Tradisi, Relasi-relasi Kuasa, dan Pencarian Wacana Baru (Yogyakarta: LKIS, 2008), 13. ${ }^{55} \mathrm{KH}$. Wahab Chasbullah adalah salah seorang aktifis SI dan berteman dekat dengan Soetomo dalam sebuah kelompok diskusi Islam Studie Club . Pada tahun 1916 dia mendirikan sebuah Madrasah dengan nama Nahdlatul Wathan sebagai pusat perjuangan faham ahl al-sunnah wa al-jama'ah, tahun 1918 mendirikan Nahdlatut Tujjar, tahun 1919 mendirikan Madrasah Tashwirul Afkar di A mpel. Lihat Andree Feillard, NU Vis-a-Vis Negara: Pencarian Isi, Bentuk, dan Makna (Yogyakarta: LKIS, 2008), 7-9.

${ }^{56}$ Benih kelahiran NU ada sejak kongres Al-Islam di Cirebon tahun 1922 di mana perdebatan tentang 'kafir' dan 'shirik' mulai bermunculan. KH. Wahab Chasabullah mengusulkan kepada KH. H asyim Asy' ari untuk membuat sebuah gerakan yang mewakili para ulama tradisionalis, tetapi Kyai Hasyim enggan menyetujuinya. Para ulama tradisional merespon ajakan untuk membuat organisasi ketika tahun 1924 terjadi perubahan besar yaitu penghapusan khalifah di Turki dan serbuan Wahabi di Makkah. Pada Bulan J anuari 1926, sebelum kongres al-Islam di Bandung, Rapat kaum pembaharu di Cianjur memutuskan untuk mengirim delegasi ke Makkah untuk menyampaikan dukungan pembersihan ibadah keagamaan di Arab Saudi. Kongres Al-Islam di Bandung tidak menyambut baik usul KH. Wahab yang menyarankan agar usul-usul kaum tradisionalis mengenai praktek keagamaan dibawa oleh delegasi Indonesia. Atas penolakan itu kaum Tradisonalis akhirnya membentuk Komite Hijaz untuk mewakili mereka menghadap Raja Malik Sa'ud. Untuk memudahkan tugas ini dibentuklah suatu organisasi yang bernama Nahdlatul Oelama (NO) pada tanggal 31 januari 1926. Ibid., 10-11.
} 
dan memperkokoh Islam tradisional di H india-Belanda. ${ }^{57}$ Organisasi yang berhaluan sama juga berdiri di Bukittinggi yaitu Persatuan Tarbiyah Islamiyah (Perti) pada tahun 1930.58

Berdirinya organisasi-organisasi modernis-tradisionalis melahirkan dinamika dan wacana vis-a-vis berhadap-hadapan dalam banyak bidang, baik bidang sosial keagamaan maupun bidang politik. Di bidang keagamaan terjadi beberapa perdebatan, hal itu dikarenakan hampir semua ajaran keagamaan Modernis berbeda dengan ajaran keagamaan Tradisionalis. Kaum Modernis -Persis dan Muhammadiyah fase ideologis ${ }^{59}$ - berusaha memberantasunsur-unsur lokal dalam kehidupan keagamaan karena dianggap bid'ah (bukan ajaran asli Islam) sementara kaum Tradisionalis mempertahankannya. ${ }^{60}$

Perdebatan yang paling dini terjadi adalah tentang niat dan pelafalan usallli*etika akan memulai shalat antara KH. Wahab Chasbullah (NU) dan Ahmad Hassan (Persis), kemudian kritik berkembang ke amalan-amalan kaum Tradisionalis lainnya seperti tahlili, slametan, dan ziarah. ${ }^{61}$ Perdebatan juga merambah ke masalah fiqih terutama masalah taqlid ${ }^{62}$ dan masalah keharusan atau tidak bermazhab. Gambaran konflik Tradisionalis (NU)-Modernis (Muhammadiyah) ini oleh G eertz dipaparkan dalam penelitiannya di Mojokuto tahuan 1950an bahwa terjadi pertentangan antara kedua kelompok tersebut sehingga orang NU tidak mau satu masjid dengan orang Muhammadiyah bahkan membuka kitab Muhammad Abduh dianggap sebagai dosa besar. ${ }^{63}$

Di bidang politik, pertentangan Tradisionalis-Modernis juga terjadi di antaranya yang terjadi pada kongres ke-4 Masyumi di Yogyakarta pada tahun 1947 di mana Natsir terpilih menjadi ketua dan para pendukungnya memenangkan mayoritas kursi di DPP, sementara Dr. Sukiman Wirjosandjojo yang didukung NU diberi jabatan Presiden Partai sebuah jabatan yang baru

\footnotetext{
${ }^{57}$ G reg Fealy, ljitihad Politik Ulama: Sejarah NU 1952-1967, ter. Farid Wajidi et.al (Yogyakarta: LKIS, 2007) 21.

${ }^{58}$ Dhurorudin Mashad, Akar Konflik, 4.

${ }^{59} \mathrm{Abdul}$ Munir Mulkhan membagi perkembangan Muhammadiyah ke dalam empat fase: Pertama, Fase Kreatifinklusif ditandai kelahiran berbagai amal usaha Muhammadiyah yang dipelopori oleh KH. Ahmad Dahlan (wafat tahun 1923). Di sini Muhammadiyah lebih tepat disebut gerakan penyadaran sosial-budaya yang menggerakkan publik untuk memecahkan persoalannya sendiri. Muhammadiyah kemudian dikenal sebagai gerakan ijtihad (pemikiran) dan tajdid (pembaharuan). Kedua, Fase Ideologis yang ditandai lahirnya lembaga fatwa shari ah dengan nama Majelis Tarjih. Di bawah kepemimpinan Mas Mansur, fase ini mengalami ideologisasi. H asil-hasil fatwa tarjih dijadikan sebagai referensi perilaku dan hubungan sosial para aktifis Muhammadiyah. Pada fase ini dikenal dengan pemberantasan TBC (tahayyul, bid'ah dan k(c)hurafat) sehingga sebutan puritanisme melakat pada Muhammadiyah yang dikaitkan dengan Wahabisme di Saudi Arabia. Ketiga, Fase spritualisasi dan sufistisasi syari'ah yang muncul pada era 90-an (di bawah kepemimpinan Amien Rais dan A hmad Syafi'i Ma'arif. pen) bersamaan dengan masuknya aktivis berpendidikan tinggi modern sekuler dari berbagai disiplin ilmu. Puncaknya pada tahun 1995 ketika Lembaga Tarjih dirubah menjadi Majelis Tarjih dan Pengembangan Pemikiran Islam dengan menempatkan fatwa shari sebagai bagian kecil, metode ijtihad (tarjib) disusun ulang bersama konsep dakwah cultural dan penempatan perempuan pada posisi kepemimpinan gerakan sebagai kelanjutan kritik doktrin puritanisme dan Wahabisme. Keempat, Fase Romantisme Puritanisme dan Wahabisme yang muncul sesudah muktamar 2005 (di Malang). Agenda spiritualitas dan sufistisasi shariłah dikoreksi ulang, lembaga fatwa shariłah (tarjik) dikembalikan ke posisi semula, dakwah kultural dan pemberian posisi pada perempuan dikaji ulang. Gerakan romantisme ini terutama dimotori aktor-aktor politik dan generasi baru alumniTimur Tengah yang kecewa terhadap posisi politik Muhammadiyah di pentas politik Nasional. RobertW. Hefner et.al. A pi Pembaharuan Kiai Ahmad Dahlan (Yogyakarta : Multi Pressindo, 2008), 18-20.

${ }^{60}$ Martin van Bruinessen, NU: Tradisi, 19

61 Ibid.,19-20.

${ }^{62}$ Ibid., 20 juga Syafiq A. Mughni, Hassan Bandung. ,97.

${ }^{63}$ Clifford Geertz, Abangan, Santri, Priyayi dalam masyarakat) awa, ter. Aswab mahasin (J akarta: Pustaka J aya, 1989), 190.
} 
diciptakan dengan kekuasaan terbatas, serta $\mathrm{KH}$ Wahab Chasbullah yang ditunjuk sebagai ketua Dewan Syura juga diberi kekuasaan terbatas melalui peraturan-peraturan baru. ${ }^{64}$ Sampai pada klimaksnya diberikannya jabatan Menteri Agama di Kabinet Wilopo (1952) kepada Fakih Usman dari Muhammadiyah, sedangkan NU menghendaki jabatan tersebut diberikan kepada Wachid H asyim sehingga memaksa NU ke luar dari keanggotaan Masyumi melalui kongres di Palembang pada A pril 1952, ${ }^{65}$ Kejadian ini dapat menimbulkan munculnya kembali permusuhan Tradisonalis - Modernis sebagaimana yang terjadi pada tahun 1920-an dan tahun 1930-an. ${ }^{66}$

Konflik politik yang sama juga terjadi di era Orde Baru ketika pemerintahan Orde ini melakukan fusi partai-partai politik menjadi dua partai politik dan satu golongan karya. Partaipartai Islam yang terdiri dari Permusi (Modernis), NU, PSII dan Perti bergabung dalam satu wadah yaitu Partai Persatuan Pembangunan (PPP) pada tanggal 5 J anuari 1973, sedangkan ONI, Murba, IPKI, Partai Katolik dan Parkindo bergabung dalam satu wadah Partai Demokrasi Indonesia (PDI) pada tanggal $10 \mathrm{~J}$ anuari $1973 .{ }^{67}$

Di awal fusi, ulama NU secara mayoritas duduk di Majelis Syuro ${ }^{68}$, sementara tokoh Permusi (setelah fusi berubah menjadi Muslimin Indonesia (MI)) duduk di kursi ekskutif. Dalam perkembangannya terjadi rivalitas antara kelompok Modernis (MI) dan kelompok Tradisionalis (NU) yang mencapai puncaknya di era kepemimpinan H.J . Naro (ia menjadi Ketua PPP sejak tahun 1978) yang banyak menyingkirkan tokoh NU di jajaran pengurus partai serta pengurangan peran orang-orang NU pada Pemilu tahun 1982, yang berakhir dengan keluarnya NU dari PPP dan kembali ke khittah 1926 melalui Muktamar ke-27 di Situbondo J awa Timur pada tahun $1984 .{ }^{69}$

\section{Fenomena Baru Islam Indonesia: Liberalis-Fundamentalis.}

Di saat mayoritas tokoh dan umat Islam Indonesia disibukkan dengan wacana pertentangan kelompok aliran baik dalam bidang keagamaan maupun politik, muncul kegelisahan pada sejumlah intelektual Islam di era tahun $1970-\mathrm{an}^{70}$, di antaranya -yang paling menonjol- adalah H arun Nasution yang dikenal dengan "Islam Rasional"-nya dan Nurcholish Madjid (Cak Nur) dengan "Sekularisasi"-nya ${ }^{71}$ yang kemudian dikenal sebagai penggerak 'pemikiran baru'. ${ }^{72}$

\footnotetext{
${ }^{64} \mathrm{G}$ reg Fealy, ljitihad Politik, 100-101.

${ }^{65}$ B.J. B Bland, "Perjuangan Islam dalam Indonesia Modern (1950-955)" dalam Islam di Asia Tenggara: Perkembangan Contemporer, ed. A hmad Ibrahim et.al, Terj. Hasan Basari (J akarta: LP3ES, 1990), 11. juga Nor Huda, Islam Nusantara: Sejarah Sosial Intelektual Islam di Indonesia, (Yogyakarta: Ar-Ruzz media, 2007), 129.

${ }^{66}$ Greg Fealy, ljitihad Politik, 97.

${ }^{67}$ Dhurorudin Mashad, Akar Konflik,84.

${ }^{68}$ Beberapa jabatan strategis dalam kepengurusan PPP awal (975) di duduki tokoh-tokoh NU. KH. B isri Syamsuri diangkat sebagai Rais 'Am Majelis Syuro, KH. Idham Cholid sebagai Presiden Partai, tetapi jabatan Ekskutif partai dijabat M intaredja seorang modernis dari MI. lihat Andree Feillard, NU Vis-a-Vis Negara, 170-171.

${ }^{69} \mathrm{bid}$., 85. lihat juga Ali Anwar, Avonturisme NU: Menjajaki Akar Konflik Kepentingan Politik Kaum Nahdhiyyin (Bandung: Humaniora, 2004), 57.

${ }^{70}$ B entuk kegelisahan-kegelisahan akan kondisi sosial-keagamaan Umat Islam Indonesia sudah menjadi renungan A hmad Wahib seorang tokoh HMI. Lihat Djohan Effendi dan Ismed Nasir, Pergolakan Pemikiran Islam Ahmad Wahib, (J akarta: LP3ES, 1981).

${ }^{71}$ Budhy Munawar -Rachman, Islam Pluralis : Wacana Kesetaraan Kaum Beriman. (J akarta: Raja Grafindo Persada, 2004), 573.

${ }^{72}$ Fachry Ali dan Bahtiar Effendy, Merambah J alan B aru Islam: Rekonstruksi Pemikiran Islam Indonesia Masa Orde Baru (Bandung: Mizan, 1992), 123.
} 
Harun Nasution yang dikenal sebagai tokoh aliran Neo-Mu'tazilah dengan tegas mengatakan bahwa agama yang diperlukan pada abad XXI adalah agama yang rasional yaitu agama yang mampu mengimbangi materialisme ilmu pengetahuan dan teknologi, dan agama yang ajaran humanismenya bersifat rasional dan terhindar dari ketinggalan zaman. ${ }^{73}$

Sementara, Nurcholish Madjis berpendapat bahwa sudah waktunya dirumuskan gerakan 'pemikiran baru', karena banyak indikasi yang menyatakan bahwa kondisi umat Islam pada waktu itu tidak menggembirakan. B erbagai organisasi seperti Muhammadiyah, al-Irsyad, Persis dan yang lain yang dulunya merupakan organisasi pembaharu Islam Indonesia pada awal abad $X X$ ternyata kehilangan dinamika ruh pembaharuannya, sementara pemimpin-pemimpin partai politik Islam baik dari NU, Perti, MI dan lain sebagainya, tidak mencerminkan penyaluran aspirasi umat Islam secara keseluruhan, melainkan hanya berfungsi untuk menyalurkan aspirasi kelompok umat Islam tertentu. ${ }^{74}$

Gagasan 'pemikiran baru' disampaikan Cak Nur melalui kertas kerjanya yang berjudul "Keharusan Pembaruan Pemikiran Islam dan Masalah Integrasi U mat". ${ }^{75}$ Dalam makalah itu la membuat tesa bahwa Umat Islam Indonesia -saat itu- telah mengalami kejumudan kembali dalam pemikiran dan pengembangan ajaran-ajaran Islam. Sebagai antitesa la menganjurkan untuk melakukan "Liberalisasi pandangan terhadap ajaran-ajaran Islam" melalui proses sekularisasi, intellectual freedom (kebebasan berfikir), idea of progress dan sikap terbuka (inclusive). Dan untuk merealisaikan cita-cita ini perlu dibentuk kelompok pembaharuan yang liberal. ${ }^{76}$

Ide liberalisasi pemikiran oleh Cak Nur mendapat reaksi beragam baik yang pro maupun yang kontra. ${ }^{77}$ Dan pemikirannya semakin mendapatreaksi keras ketika la menyampaikan pidato keagamaan "Beberapa Renungan tentang Kehidupan Keagamaan di Indonesia" di Taman Ismail Marzuki (TIM) J akarta pada tanggal 21 Oktober 1992 -terutama- dari kelompok fundamentalis, karena kelompok ini tersinggung dengan istilah yang digunakan Cak Nur bahwa gerakan fundamentalis sebagai sesuatu yang berbahaya sebagaimana bahaya narkotika. ${ }^{78}$

Gerakan liberalisasi pemikiran Islam di Indonesia yang dirintis kedua tokoh tersebut serta ditambah gerakan arus pemikiran kontemporer yang berkembang di dunia Islam ${ }^{79}$ dan Barat,, 80

\footnotetext{
${ }^{73}$ Budhy Munawar -Rachman, Islam Pluralis. 574. Lebih lanjut tentang gagasan Harun Nasution, lihat. Harun Nasution, Islam Rasional.

${ }^{74}$ Ibid., 125-127

${ }^{75} \mathrm{G}$ agasan ini disampaikan di hadapan peserta silaturrahim aktifis dan anggota empat organisasi yaitu Persami, HMI, GPI dan PII yang diselenggarakan PII Cabang J akarta pada tanggal 3 J anuari 1970. Lihat. Nurcholish Madjid, Islam Kemodernan dan Kelndonesiaan (Bandung: Mizan, 1992), 325.

${ }^{76}$ lbid., 204-214.

${ }^{77} \mathrm{Di}$ antara pandangan kontra dengan gagasan Cak Nur yang berhasil terlacak antara lain HM. Rasjidi, Koreksi terhadap Drs. Nurcholish Madjid tentang Sekularisasi (J akarta: Bulan Bintang, 1977), Endang Saefuddin Anshari, Kritik atas Faham dan Gerakan Pembaharuan Nurcholish Madjid (Bandung: Bulan Sabit, 1973).

${ }^{78}$ Budi Handrianto, 50 Tokoh Islam Liberal Indonesia Pengusung Ide Sekularisme, Pluralisme, dan Liberalisme Agama (J akarta: H ujjah Press, 2007), 58.

${ }^{79} \mathrm{G}$ erakan pemikiran kontemporer hampir tumbuh di seluruh dunia Islam. Di Mesir sejumlah tokoh yang dikenal antara lain Ali Abd Raziq, Tahah Husein, ZakiæN aqaib Machmud, Rif'at Thahtawi, Hasan Hanafi, Nasr Hamid Abu Zayd, dll. Di Maroko ada Muhammad 'A bid al-J abiri, Thayib Tizani>Thaha Abdurrahman, dll. Lihat Shalahuddin J ursyi, Membumikan Islam Progresif ter. M. Aunul Abied Syah (J akarta: Paramadina, 2004), vii-viii.

${ }^{80}$ Pengaruh B arat yang dimaksud adalah perkembangan paradigma Filsafat Post-Strukturalis dan Post-Modernis. Post-Strukturalis merupakan kelanjutan dari aliran filsafat Strukturalis yang dimotori oleh Ferdinand D. Sausure, Claude Levi Strauss (yang dianggap sebagai bapak strukturalisme). Post-Strukturalis dimotori oleh Louis Althusser,
} 
dalam waktu kurang dari satu dasawarsa mampu mendekonstruksi pola pemikiran umat Islam Indonesia terutama kaum muda-nya. Dekonstruksi yang dimaksud adalah semakin mencairnya kelompok aliran, semakin menipisnya konflik faham keagamaan dan polarisasi pilihan politik baik oleh kelompok Tradisionalis (NU) maupun kelompok Modernis (Muhammadiyah).

Di kalangan kaum muda NU ada sejumlah indikasi yang menunjukkan gerak perubahan wacana keislaman antara lain; pertama, kecenderngan semakin pudarnya kepatuhan mereka terhadap fatwa ulama dan bangkitnya kreatifitas individu kalangan muda dalam berfatwa. Kedua, kecenderungan semakin melemahnya penonjolan pada masalah-masalah fiqhiyah dan tampak kian menonjol isu-isu kemanusian. Ketiga, kecenderungan yang ditandai semakin lemahnya sikap-sikap sektarian dan semakin tumbuhnya sikap non sektarian. ${ }^{81}$

Tidak hanya tokoh muda NU, para senior mereka juga memberikan angin sejuk atas perubahan ini. Hal ini dapat diidentifikasi banyaknya para kyai yang berhaluan moderat dan welcome terhadap pemikiran kontemporer di samping sikap-sikap lain oleh kalangan Nahdliyin. ${ }^{82}$

Perubahan wacana pemikiran di kalangan muda Nahdliyin ini melahirkan sejumlah organisasi atau kelompok studi baik di dalam struktur NU seperti Lakpesdam (Lembaga Kajian dan Pengembangan Sumberdaya Manusia) NU di J akarta, maupun di luar struktur NU (sebagian di antara anggotanya ada yang bukan dari NU) seperti LKiS (Lembaga Kajian dan Sosial) di Yogyakarta, LKPSM (Lembaga Kajian dan Pengembangan Sumber Daya Manusia) di Pondok Pesantren Nurul U mmah Kotagede Yogyakarta, P3M (Perhimpunan Pengembangan Pesantren dan Masyarakat) di Kramatjati J akarta, dan J IL (J aringan Islam Liberal) di Utan Kayu J akarta, serta eLSAD (Lembaga Studi Agama dan Demokrasi) di Surabaya. ${ }^{83}$

Di Muhammadiyah perubahan wacana pemikiran - meskipun tidak sepesat di NU- juga terjadi baik berbentuk organisasi atau kelompok studi, semisalnya IMM (J aringan Intektual Muda Muhammadiyah yang didirikan pada tanggal 12 O kto ber 2003, PSAP (Pusat Studi Agama dan Peradaban), al-Ma'un Institut, Ma'arif Institut yang kesemuanya berdiri karena sikap akomodatif terhadap pembaharuan Islam di Muhammadiyah di era Ahmad Syafi'i Ma'arif. ${ }^{84}$

Merespon semakin maraknya pemikiran Islam Liberal, muncul perlawanan dari sekelompok umat Islam yang mempunyai pemahaman sebaliknya tentang Islam. Kelompok ini kemudian dikenal dengan Fundamentalis. Secara umum, cita-cita dan orientasi gerakan Islam fundamental adalah untuk mendapatkan kembali The Golden Age of Islam melalui tahapan-tahapan: G erakan Islam G lobal (G lobal Islamic M ovement), agar bisa mengadakan suatu Rovolusi Islam (Islamic

Paul Ricoeur, Alain Touraine, J acques Lacan, Roland Barthes, dan Michel Foucault. Lihat Anthony Giddens dan J onathan Turner, Social Theory Today: Panduan Sistematis Tradisi dan Tren Terdepan Teori Sosial, ter. Yudi Santoso (Yogyakarta: Pustaka Pelajar, 2008), 333. J uga Edith Kurzweil, J aringan, 1-17. Sedangkan Post-Modernisme merupakan kelanjutan dan sekaligus kritik atas Modernisme. Aliran ini muncul sekitar tahun 1950-an yang pada awalnya untuk bidang arsitektur yang kemudian berkembang untuk seluruh bidang Kultural. Di antara tokoh aliran ini adalah Francois Lyotard, J acques Derrida, Richard Porty, Michel Foucoult. lihat. Tony Pinkney, "Modernisme and Postmodernisme" dalam Kamus Lengkap Pemikiran Sosial Modern, ed. William Outhwaite ter. Tri Wibowo (J akarta: Kencana Prenada Media Group,, 2008), 524. J uga George Ritzer dan DouglasJ Goodman, Teori Sosial, 628.

${ }^{81}$ Ahmad Ali Riyadi, Dekonstruksi Tradisi Kaum Muda NU Merobek Tradisi (Yogyakarta: Ar-Ruzz Media, 2007), 31.

${ }^{82}$ Ali Maschan Moesa, Nasionalisme Kyai: Konstruksi Sosial Berbasis Agama (Yogyakarta: Elkis, 2007),286.

${ }^{83} \mathrm{Ibid} ., 60-79$. lihat juga Shonhadji Sholeh, Arus Baru NU: Perubahan Kaum Muda dari Tradisionalisme ke PosTradisionalisme (Surabaya: J P Books, 2004), 50.

${ }^{84}$ Deni al-Asy'ari, Pemberontakan Kaum Muda Muhammadiyah (Yogyakarta: Resist Book, 2005), 27. 
Revolution), dan akhirnya dapat menciptakan Negara Islam (Islamic State). ${ }^{85}$

Menggunakan di antara tahapan-tapahan tersebut di Indonesia, akar gerakan fundamentalis yang berbentuk purifikasi dapat dilacak pada awal abad ke-19 di Minangkabau yaitu ketika sekelompok pemuka Islam pulang dari Makkah dan membentuk Dewan H arimau nan Salapan atau Dewan Tuangku Nan Salapan yang menjelma menjadi gerakan Padri yang melakukan usaha pemurnian Islam menurut ide dan cara kaum Wahabiyah di Saudi Arabia. ${ }^{86}$

Sedangkan keinginan merealisasikan Negara Islam dapat dilihat ketika Soekarmadji Marijan (SM) Kartosuwiryo mendirikan Negara Islam Indonesia (NII) yang diproklamirkan pada 7 Agustus 1949, dan kemudian mengadakan gerakan bersenjata DI/TII pada tahun 1950 di J awa Barat. NII menjadi meluas dengan bergabungnya gerakan Kahar Muzakar di Sulawesi Selatan, dan Gerakan Daud Beureuh di Aceh. ${ }^{87}$ Di era Orde Baru -meskipun pemerintah bertindak represif dan pelakunya dianggap subversif- aksi-aksi teror -yang menunjukkan eksistensi kelompok initerjadi di antara, pada tahun 1976 oleh kelompok yang menamakan Komando J ihad yang dimotori oleh mantan pimpinan Negara Islam Indonesia (NII) Ismail Pranoto yang kemudian dilanjutkan oleh kelompok Warman. Pada tahun 1977 oleh Front Pembela Muslim Indonesia (FPMI) yang dipimpin oleh $\mathrm{H}$ asan Tiro yang mencoba membentuk Negara Aceh Merdeka dengan shariłat Islam. Pada tahun 1978 oleh Pola Perjuangan Revolusioner Islam yang dipimpin oleh Abdul Qadir J aelani. Pada tahun 1980 oleh Dewan Revolusi Islam Indonesia yang dipimpin oleh Imron, yang menarik karena membajak pesawat Garuda DC-9 tahun $1981 .{ }^{88}$

Kelompok Islam Radikal di Indonesia -yang kemudian dikenal dengan- Gerakan Salafi Militan (GSM) ${ }^{89}$ tumbuh subur ketika kekuasaan Orde Baru tumbang. Di era pemerintahan Presiden Habibi, GSM mengalami eforia yang ditandai dengan berdirinya Fron Pembela Islam (FPI) yang dideklarasikan di Pondok Pesantren AI-U mm Cempaka Putih Ciputat pada 17 Agustus 1998 yang dipimpin oleh Habib Muhammad Rizieq Shihab. ${ }^{90}$ Lasykar J ihad Ahlu al-Sunnah meskipun berdirinya organisasi ini dilatar belakangi oleh konflik di Ambon, tetapi orientasi perjuangan kelompok ini mengembangkan aliran Wahabi di Indoneia yang dianggap sebagai

\footnotetext{
${ }^{85}$ Kalim Siddiqui, Seruan-seruan Islam: Tanggung J awab Sosial dan Kewajiban Menegakkan Syari'at, ter. Akhmad Affandi dan Humaidi (Yogyakarta: Pustaka Pelajar, 2002).

${ }^{86}$ Burhanuddin Daya, Gerakan Pembaharuan Pemikiran Islam: Kasus Sumatera Thawalib,(Yogyakarta: Tiara Wacana, 1995), 50.

${ }^{87}$ Tuntutan Penerapan shari at Islam di daerah-daerah seperti di J awa Barat, Sulawesi Selatan, Nangroe Aceh Darussalam dan daerah lainya - diistilahkan oleh Haedar Nashir- sebagai Penerapan Shari sat Islam"J alur Bawah", sedankan keinginan penerapan shari.ah secara Nasional yang diusung oleh HTI dan M MI disebut Penerapan Shariat Islam "J alur Atas". Lihat Haedar Nashir, Gerakan Islam Syari'at: Reproduksi Salafiyah Ideologis di Indonesia (J akarta: PSAP Muhammadiyah, 2007),282 dan 386.

${ }^{88}$ M. Zaki M ubarak, Geneologi Islam Radikal di Indonesia: Gerakan Pemikiran dan Prospek Demokrasi (J akarta: LP3ES, 2007)., 72-73

${ }^{89}$ Ibid., xii. Ciri khas penampilan kaum salafi secara fisik terlihat memakai jalabiyah (jubah panjang), 'imamah (serban), isbal (celana yang panjangnya hanya sampai mata kaki) dan lihyah (jenggot), serta kalangan perempuannya menggunakan niqab (bentuk pakaian warna hitam yang menyelubungi seluruh tubuh). Mereka membedakan diri dengan masyarakat pada umumnya dengan mengorganisir komunitas kecil untuk menerapkan "Islam murni" dengan mencontoh pada tradisi $\mathrm{Nabi}$ dan al-salaf al-sălih yang berbeda dengan model kehidupan masyarakat model Barat. Lihat N oorhaidi Hasan, Laskar J ihad: Islam, Militansi, dan Pencarian Identitas di Indonesia Pasca Orde Baru (J akarta: Pustaka LP3ES dan KITLV, 2008), 31.

${ }^{90}$ Tentang visi dan misi pendirian FPI, lihat. Andri Rosadi. Hitam Putih FPI (Fron Pembela Islam). (J akarta: Nur Publisher, 2008). Dan bandingkan dengan A I-Zastrouw N g. Gerakan Islam Simbolik: Politik Kepentingan FPI (Yogyakarta: LKiS, 2006).
} 
gerakan Salafi. Laskar J ihad diresmikan pada 14 Februari 1998 dengan panglima Dja'far U mar Thalib. Majelis Mujahidin Indonesia (M MI) yang dideklarasikan pada tanggal 7 Agustus 2008 sebagai kesimpulan dari kongres MMI di Yogyakarta yang menetapkan Abu Bakar Ba'asyir sebagai Amir Mujahidin.

Selain itu, terdapat sayap yang berkonsentrasi untuk mengorganisir generai muda antara lain, H izbut Tahrir Indonesia (HTI), organisasi yang mengusung khilafah Islamiyah ini masuk ke Indonesia sekitar tahun 1980-an oleh seorang muballigh dari Yordania berkebangsaan Australia Abdurrahman al-Baghdadi yang pernah diundang oleh $\mathrm{KH}$. Abdullah bin Nuh pimpinan Pondok Pesantren al-G hazali Bogor. HTI lebih memokuskan perjuangan di kampus-kampus di seluruh Indonesia. KAMMI (Kesatuan Aksi Mahasiswa Muslim Indonesia), dan HAMMAS (Himpunan Aksi Mahasiswa Muslim antar Kampus). ${ }^{91}$

Para pengikut Islam Fundamentalis di Indonesia, didentifikasi lebih banyak berasal dari kelompok Islam yang pernah mengusung jargon purifikasi seperti Persis, Muhammadiyah dan al-Irsyad. ${ }^{92} \mathrm{Hal}$ itu dapat dilihat di antaranya dari para aktifis gerakan ini. J a'far U mar Thalib Panglima Lasykar Jihad adalah Ketua DPP Pelajar Al-Irsyad (1985-1986) dan Pemimpin Pesantren Al-Irsyad Salatiga (1989-1991), ${ }^{93}$ sedangkan A mrozi dan Ali G hufron (keduanya pelaku bom Bali yang sudah diekskusi mati) berlatar belakang keluarga Muhammadiyah, ${ }^{94}$ dan Abdul Aziz alias Imam Samudara (juga pelaku bom Bali) berlatar belakang keluarga Persis. ${ }^{95}$

Meskipun demikian, dari kalangan NU juga terdapat generasi muda mereka yang masuk dalam arus pusaran GSM, di antaranya adalah Alifah seorang anak aktifis NU yang karena bergaul dengan kelompok ini sewaktu kuliah di UG M akhirnya ia juga menjadi pengikut dan penyebar aliran Salafi. ${ }^{96}$

\section{Pergeseran Konflik: dari Tradisionalis-Modernis ke Liberalis-Fundamentalis.}

Semakin memudarnya ikatan primordial antara kelompok Islam Modernis dan Tradisionalis di Indonesia akan menjadikan potensi konflik di antara kedua-nya semakin mereda. Meskipun demikian, bukan berarti akan menjadikan Indonesia ke depan terbebas dari konflik intern umat beragama (Islam). Hal itu ditengarai adanya fenomena pergeseran konflik antara Islam Fundamentalis dan Islam Liberalis.

Fenomena konflik antar dua kelompok ini sangat dimungkinkan karena keduanya mempunyai cara pandangan dan logika berfikir yang berbalik dalam memaknai Islam sehingga agenda masing-masing kelompok tentu berbeda. Berikut beberapa pandangan yang berbeda di antara keduanya yang berimplikasi pada agenda gerakan.

\footnotetext{
${ }^{91}$ M. Zaki Mubarak, Geneologi Islam, 116-132. juga Ibid., 3.

92 Muh. Ikhsan, "Gerakan Salafi di Indonesia:Sebuah Upaya Membedah Akar Pertumbuhan dan Ide-Ide Substansialnya,", dalam http://abulmiqdad.multiply.com. (1 Desember 2008)

${ }_{93}$ J a'far U mar Thalib, http://www.ghabo.com.

${ }_{94} \mathrm{H}$ arian Sore Surabaya Post “Kakek Buyut Amrozi Kyai Besar", dalam http://www.surabapost.co.id (3 Desember 2008)

${ }^{95}$ Zulkifli H aji Mohd Yusoff \& Fikri Mahmud, "Gerakan Teroris dalam Masyarakat Islam : Analisis terhaap Gerakan J emaah Islamiyah (J I)", dalam http://fikrimahmud.tripod.com (3Desember 2008).

${ }_{96}^{96}$ Imam Subkhan, H iruk Pikuk Wacana Pluralisme di Yogya (Yogyakarta: Kanisius, 2007).
} 
Pertama, di bidang politik. Muslim liberal berpandangan bahwa persoalan politik adalah masalah ijtihadi>yang diserahkan sepenuhnya kepada kaum muslimin, bentuk negara dan pemerintahan berupa republik, kerajaan, parlementer, atau presidential diserahkan pada kesepakatan anak bangsa. Sedangkan Muslim Fundamentalis berpandangan bahwa bentuk negara adalah khilafah dengan dasar shariłat Islam. ${ }^{97}$

Kedua, menyangkut hubungan internal umat Islam dan antar umat beragama. Kelompok Liberal meyebarkan faham pluralisme, inklusifme dan toleransi, serta welcome bahkan terpesona terhadap peradaban Barat, sebaliknya Islam Fundamentalis cenderung mengembangkan anti pluralis, eksklusif, menganggap agama lain sebagai orang kafir dan kelompok terkutuk serta mempercayai secara berlebihan teori konspirasi Barat dan umat Islam sebagai korbannya. ${ }^{98}$

Ketiga, tentang emansipasi wanita. Kelompok liberal berkeinginan kuat mendekonstruksi beberapa doktrin Islam yang cenderung mendiskreditkan dan merugikan kaum wanita melalui gerakan feminisme dan persamaan gender. Sedangkan Islam Fundamentalis lebih membatasi emansipasi secara konservatif pada kewajiban wanita di sekitar rumah tangga, memakai jilbab, melayani suami dan membolehkan suami untuk berpoligami. ${ }^{99}$

Keempat, tentang kebebasan berpendapat. Islam liberal sangat menghargai kebebasan berfikir dan berpendapat karena merupakan wilayah private seseorang, yang dibatasi hanyalah kebebsan berekspresi karena -jika dilakukan secara berlebihan- akan berbenturan dengan wilayah Negara. Sedangkan Islam Fundamentalis lebih cenderung mempromosikan peradaban tekstual Islam. ${ }^{100}$

Kasus-kasus aktual yang menandai adanya konflik -tidak sebatas wacana- antara Islam Liberalis di antaranya adalah dikeluarkannya fatwa "hukuman mati" kepada U lil A bshar Abdalla (Koordinator J IL) yang dirumuskan dalam acara silaturrahmi sebagian umat Islam di J awa Barat, J awa tengah dan J awa Timur oleh Forum Ulama-Umat Islam (FUUI) pimpinan KH. Athian Ali di Masjid al-Fajar Bandung, karena tulisan U lil yang berjudul “Menyegarkan Kembali Pemahaman Islam" yang dimuat di harian Kompas pada tanggal 12 Nopember 2002. ${ }^{101}$

Kasus yang hampir serupa -yaitu pembunuhan karakter- yang terjadi di internal Muhammadiyah, peristiwa dikeluarkannya Moh. Shofan sebagai staf pengajar di Fakultas Tarbiyah Universitas Muhammadiyah Gresik atas desakan Pimpinan Daerah Muhammadiyah (PDM) Kabupaten G resik yang menganggap la menyebarkan ajaran SePILIS (Sekularisme, Pluralisme dan Liberalisme Agama) hanya karena yang bersangkutan menulis sebuah artikel "Natal dan Pluralisme Agama" yang dimuat di harian Surya Desember 2006. ${ }^{102}$

Dan yang paling aktual adalah bentrokan antara massa Front Pembela Islam (FPI) dan

\footnotetext{
${ }^{97}$ Luthfi Assyaukanie, Islam Benar vs Islam Salah (J akarta: Kata Kita, 2007), 71. bandingkan dengan Kalim Siddiqui, Seruan-seruan Islam, 27 dan Haedar N ashir, Gerakan Islam Syari'at, 386.

${ }^{98}$ Luthfi Assyaukanie, Islam Benar, 73. bandingkan dengan M. Zaki Mubarak, Geneologi Islam., xviii-xix

${ }^{99}$ Luthfi Assyaukanie, Islam Benar, 74 bandingkan dengan Salafy, "Kedudukan Wanita Dalam Islam (1)" dalam www.islam-download.net.

${ }^{100}$ Luthfi Assyaukanie, Islam B enar, 74 bandingkan dengan M. Zaki Mubarak, Geneologi Islam, xvii

101 Ulil Abshar Abdalla et.al. Islam Liberal dan Fundamental: sebuah Pertarungan Wacana (Yogyakarta: eLSAQ Press, 2007).

102 Moh. Shofan et.al. Menegakkan Pluralisme: Fundamentalisme-Konservatifme di Tubuh M uhammadiyah (J akarta: LSAF-Ar Ruzz Media, 2008).
} 
Aliansi Kebangsaan untuk Kebebasan Beragama dan Berkeyakinan (AKKBB), yang terjadi hari Minggu 1 J uni 2008 di silang Monas J akarta karena pembelaan Aliansi ini atas berbagai hal, di antaranya soal Ahmadiyah. ${ }^{103}$

Di tengah-tengah pertarungan tersebut, kelompok Islam fundamental seakan mendapatkan legitimasi, ketika Majelis Ulama Indonesia (MUI) dalam Munas ke-7 tanggal 28 September 2005 mengeluarkan 11 fatwa yang di antaranya butir (6) MUI mengharamkan pluralisme (pandangan yang menganggap semua agama sama), sekularisme, dan liberalisme. ${ }^{104}$

\section{Kesimpulan.}

Dari uraian di atas, dapat disimpulkan bahwa terdapat fenomena pergeseran konflik dari Tradisionalis-Modernis ke Liberalis-Fundamentalis yang dapat digambarkan sebagai berikut.

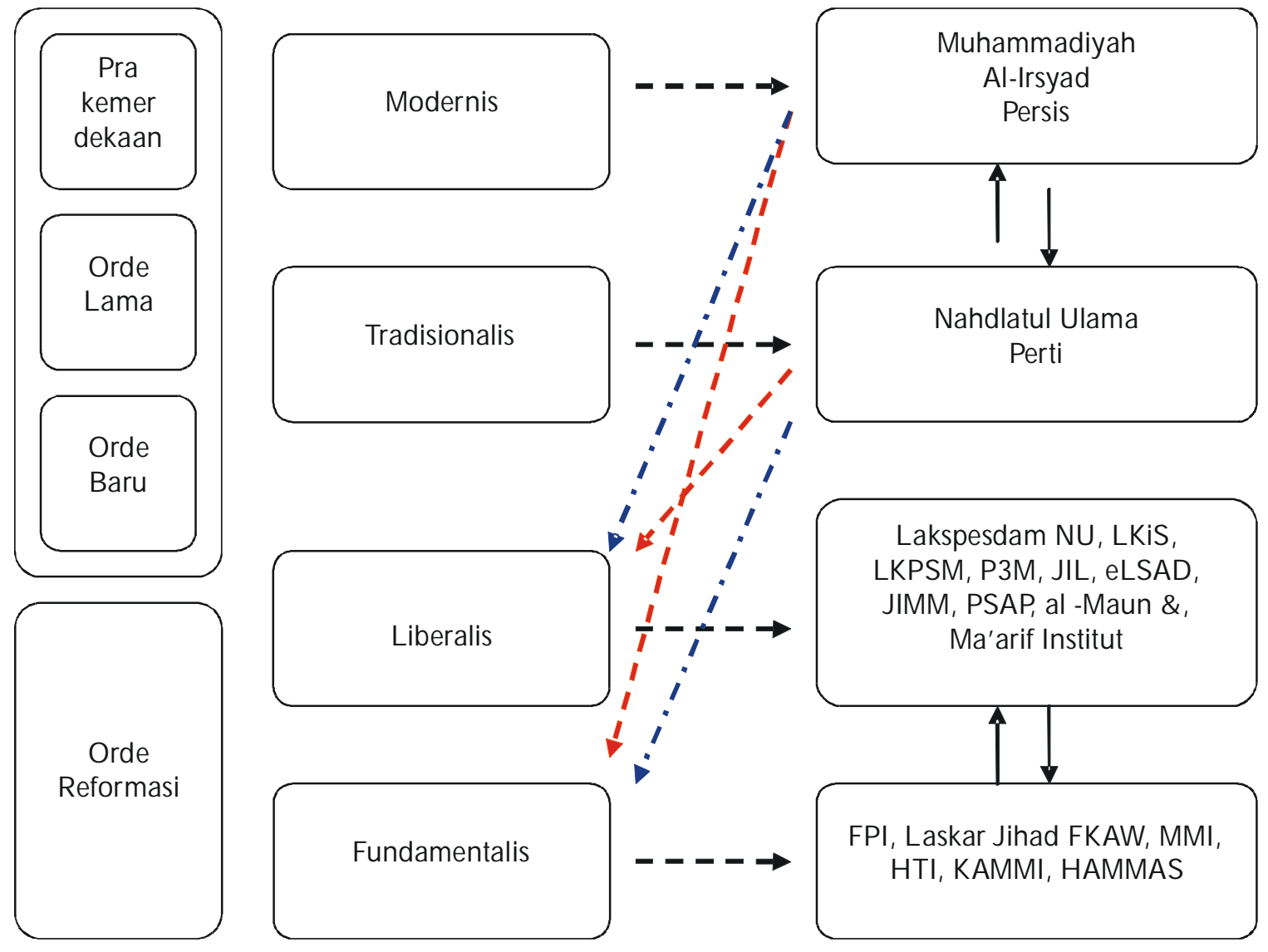

Gambar 3 : Peta Pergeseran konflik dari tradisionalis-modernis ke liberalis-fundamentalis

${ }^{103}$ A chmad Setiyadi, Tragedi M onas Berdarah (Bandung: Semesta Investigation, 2008).

${ }^{104}$ Budi Handrianto, 50 Tokoh Islam, xii. 


\section{Daftar Rujukan}

Abdalla, Ulil Abshar. et.al. Islam Liberal dan Fundamental: sebuah Pertarungan Wacana. Yogyakarta : eLSAQ Press, 2007.

Adonis. Arkeologi Sejarah Pemikiran Arab-Islam, Terj. Khairon Nahdiyyin. Yogyakarta: LKIS, 2007.

Ahmed, Akbar S. Posmodernisme: Bahasa dan Harapan Bagi Islam ter. M. Sirozi. Bandung: Mizan, 1993.

Ali, Fachry dan Bahtiar Effendy. Merambah J alan Baru Islam: Rekonstruksi Pemikiran Islam Indonesia Masa Orde Baru. Bandung: Mizan, 1992.

Anshari, Endang Saefuddin. Kritik atas Faham dan Gerakan Pembaharuan Nurcholish Madjid. Bandung: Bulan Sabit, 1973.

Anwar, Ali. Avonturisme NU: Menjajaki Akar Konflik Kepentingan Politik Kaum Nahdhiyyin. Bandung: Humaniora, 2004.

Assyaukanie, Luthfi. Islam Benar vs Islam Salah. J akarta : Kata Kita, 2007.

al-Asy'ari, Deni. Pemberontakan Kaum Muda M uhammadiyah. Yogyakarta: Resist Book, 2005. Azra, Azyumardi. J aringan Ulama Timur Tengah dan Kepulauan Nusantara Abad XVII - XVIII. J akarta: Kencana, 2007.

Black, Anthony. Pemikiran Politik Islam dari Masa Nabi hingga Masa Kini ter. Abdullah Ali et.al. J akarta: Serambi, 2006.

Boswort, G .E. Dinasti-dinasti Islam ter. Ilyas H asan. Bandung: Mizan, 1993.

Boullata, Issa J. Trends and Issues in Contemporery Arab Thougt. Albany: State University of New York Press, 1990.

Bruinessen, Martin van. NU: Tradisi, Relasi-relasi Kuasa, dan Pencarian Wacana Baru. Yogyakarta: LKIS, 2008.

Daya, Burhanuddin. Gerakan Pembaharuan Pemikiran Islam: Kasus Sumatera Thawalib. Yogyakarta: Tiara Wacana, 1995.

Effendi, Djohan dan Ismed Nasir. Pergolakan Pemikiran Islam Ahmad Wahib. J akarta: LP3ES, 1981.

Fealy, Greg. Ijitihad Politik Ulama: Sejarah NU 1952-1967 ter. Farid Wajidi et.al. Yogyakarta: LKIS, 2007.

Feillard, Andree. NU Vis-a-Vis Negara : Pencarian Isi, Bentuk, dan Makna . Yogyakarta: LKIS, 2008.

Geert, Clifford. Abangan, Santri, Priyayi dalam Masyarakat J awa ter. Aswab Mahasin. J akarta: Pustaka J aya, 1989.

Giddens, Anthony dan J onathan Turner. Social Theory Today: Panduan Sistematis Tradisi dan Tren Terdepan Teori Sosial. ter. Yudi Santoso. Yogyakarta: Pustaka Pelajar, 2008.

H all, D.G .E. Sejarah Asia Tenggara ter. IP. Soewarsha. Surabaya: U saha Nasional, 1988.

Hasan, Noorhaidi. Laskar J ihad: Islam, Militansi, dan Pencarian Identitas di Indonesia Pasca Orde Baru. J akarta: Pustaka LP3ES danKITLV, 2008.

Hefner, RobertW. et.al. A pi Pembaharuan Kiai Ahmad Dahlan. Yogyakarta: Multi Pressindo, 2008. 
Hitti, Philip K. H istory of the Arabs, terj. Cecep Lukman Yasin, et.al. J akarta: Serambi Ilmu Semesta, 2005.

H odgson, Marshall G.S. The Venture of Islam : Iman dan Sejarah dalam Peradaban Islam, Buku Pertama Lahirnya sebuah Tatanan Baru ter. Mulyadhi Kartanegara. J akarta: Paramadina, 2002.

H uda, Nor. Islam Nusantara: Sejarah Sosial Intelektual Islam di Indonesia. Yogyakarta: Ar-Ruzz media, 2007.

Ibrahim, Ahmad et.al. (ed). Islam di Asia Tenggara: Perkembangan ontemporer. ter. Hasan Basari. J akarta: LP3ES, 1990.

al-J abiri>Muhł̧mmad 'A bid. Takwin al-'Aql al-Arabi>Beirut: al-Markazal-Thaqafiæal-Arabi>1991. J ainuri, Achmad. Ideologi Kaum Reformis: Melacak Pandangan Keagamaam M uhammadiyah Periode Awal. Surabaya: LPAM, 2002.

J ursyi, Shalahuddin. Membumikan Islam Progresif ter. M. Aunul Abied Syah. Jakarta: Paramadina, 2004.

Karpat, Kemal K. Political and social in The Contemporary Middle East. New York: Praeger Publishers, 1982.

Khalil, Ahmad. Islam J awa: Sufisme dalam Etika dan Tradisi J awa. Malang: UIN Malang Press, 2008.

Kurzman, Charles (ed). Wacana Islam Liberal: Pemikiran Islam Kontemporer tentang Isu-Isu Global ter. Bahrul Ulum dan H eri J unaidi. J akarta: Paramadina, 2003.

Kurzweil, Edith. J aringan Kuasa Strukturalisme ter. Nurhadi. Yogyakarta: Kreasi Wacana, 2004. Lapidus. Ira M. Sejarah Sosial U mmat Islam Bagian Kesatu dan Kedua ter.G hufron A. Mas'adi. J akarta: Rajawali Pers, 1999.

Lecthe, J ohn. 50 Filsuf Kontemporer: dari Strukturalisme sampai Postmodernisme, ter. Gunawan Admiranto. Yogyakarta: Kanisius, 2001.

Loir , H enri Chambert. dan Claude G uillot (ed). Ziarah dan Wali di Dunia Islam ter. J ean Couteau et.al. J akarta: Serambi, 2007.

Madjid, Nurcholish. Islam Kemodernan dan Kelndonesiaan. Bandung: Mizan, 1992.

- - - - . Islam Doktrin dan Peradaban: Sebuah Tela'ah Kritis tentang Masalah Keimanan, Kemanusiaan, dan Kemodernan. J akarta: Yayasan Wakaf Paramadina, 1992.

- - - - . (ed). Khazanah Intelektual Islam. J akarta: Bulan Bintang, 1985.

Mashad, Dhurorudin. Akar Konflik Politik Islam di Indonesia. J akarta: Pustaka al-Kautsar, 2008. Moesa, Ali Maschan. Nasionalisme Kyai: Konstruksi Sosial Berbasis Agama. Yogyakarta: Elkis, 2007.

Mubarak, M. Zaki. Geneologi Islam Radikal di Indonesia: Gerakan Pemikiran dan Prospek Demokrasi. J akarta: LP3ES, 2007.

Mughni, Syafiq A. Hassan Bandung Pemikir Islam Radikal. Surabaya: Bina IImu, 1994.

Mulyati, Sri. Mengenal dan Memahami Tarekat-tarekat Muktabarah di Indonesia. Jakarta: Kencana, 2006.

Nashir, Haedar. Gerakan Islam Syari'at: Reproduksi Salafiyah Ideologis di Indonesia. J akarta: 
PSAP Muhammadiyah, 2007.

Nasution, Harun. Islam Rasional: Gagasan dan Pemikiran Prof. DR. Harun Nasution. Bandung: Mizan, 1995.

- - - - . Islam ditinjau dari berbagai aspeknya J ilid I. J akarta: UI P ress, 1985.

- - - - Pembaharuan Dalam Islam: Sejarah Pemikiran dan Gerakan. Jakarta: Bulan Bintang, 1975.

Outhwaite, William (ed). Kamus Lengkap Pemikiran Sosial M odern, ed. ter. Tri Wibowo. J akarta: Kencana Prenada Media Group, 2008.

Pasha, Musthafa Kamal dan Ahmad Adaby Darban. Muhammadiyah sebagai Gerakan Islam: dalam Perspektif Historis dan Ideologis. Yogyakarta: LPPI, 2003.

Rachman, Budhy Munawar. Islam Pluralis: Wacana Kesetaraan Kaum Beriman. J akarta: Raja Grafindo Persada, 2004.

- - - - ed). Kontekstualisasi Doktrin Islam dalam Sejarah. J akarta: Yayasan Wakaf Paramadina, 1994.

Raffles, Thomas Stamford. The H istory of J ava ter. Eko Praseyoningrum et.al. Yogyakarta: Narasi, 2008

Rasjidi, HM. Koreksi Terhadap Drs. Nurcholish Madjid tentang Sekularisasi. J akarta: Bulan Bintang, 1977.

Ricklefs, M.C. Sejarah Indonesia Modern 1200-2004 ter. Satrio Wahono. et.al. J akarta: PT. Serambi Ilmu Semesta, 2005.

Ritzer, George dan Douglas J G oodman. Teori Sosial Modern, ter. Alimandan. J akarta: Kencana Prenada Media Group, 2004.

- - - - - Teori Sosial Post-M odern ter. Muhammad Taufik. Yogyakarta: Kreasi Wacana, 2008.

Riyadi, Ahmad Ali. Dekonstruksi Tradisi Kaum Muda NU Merobek Tradisi. Yogyakarta: Ar-Ruzz Media, 2007.

Rosadi, Andri. Hitam Putih FPI (Fron Pembela Islam. J akarta: Nur Publisher, 2008.

Setiyadi, Achmad. Tragedi M onas Berdarah. Bandung: Semesta Investigation, 2008.

Siddiqui, Kalim. Seruan-seruan Islam: Tanggung J awab Sosial dan Kewajiban Menegakkan

Syari'at, ter. Akhmad Affandi dan Humaidi. Yogyakarta: Pustaka Pelajar, 2002.

Shofan, Moh. et.al. Menegakkan Pluralisme: Fundamentalisme-Konservatifme di Tubuh Muhammadiyah . J akarta: LSAF-Ar Ruz Media, 2008.

Sholeh, Shonhadji. Arus Baru NU: Perubahan Kaum Muda dari Tradisionalisme ke PosTradisionalisme. Surabaya: J P Books, 2004.

Syalabi. Sejarah dan Kebudayaan Islam . J akata: Pustaka al-H usna, 1994.

Subkhan, Imam. H iruk Pikuk Wacana Pluralisme di Yogya. Yogyakarta: Kanisius, 2007.

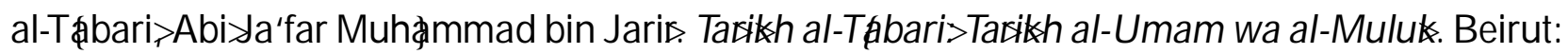
Dasal-Kutub al-'Ilmiyah, 2005.

Thabathaba'i, 'Allamah M.H. Islam Syi'ah: Asal-usul dan Perkembangannya, ter. Djohan Effendi. J akarta: Pustaka Utama G rafindo, 1993.

Wahhab, 'Abdul. Kitab Tauhid ter. Abdul Qadir et.al. Bandung: Pustaka, 1987. 
Watt, W. Montgomery. Studi Islam Klasik: Wacana Kritik Sejarah ter. Sukoyo et. al. Yogyakarta: Tiara Wacana,1999.

Woodward, Mark R. Islam Jawa Kesalehan Normatif Versus Kebatinan ter. Hairus Salim. Yogyakarta: LKIS, 2008.

al-Zastrouw Ng. Gerakan Islam Simbolik: Politik Kepentingan FPI . Yogyakarta : LKiS, 2006.

\section{Internet:}

Assyaukanie, A. Luthfi. "Tipologi dan Wacana Pemikiran Arab Kontemporer", dalam http:media.isnet.org

Harian Sore Surabaya Post "Kakek Buyut Amrozi Kyai Besar", dalam http://www. surabapost.co.id (3 Desember 200)

Ikhsan, Muh. "Gerakan Salafi di Indonesia :Sebuah U paya Membedah Akar Pertumbuhan dan Ide-Ide Substansialnya,", dalam http://abulmiqdad.multiply.com. (1 Desember 2008) J a'far Umar Thalib, http://www.ghabo.com.

Salafy, "Kedudukan Wanita Dalam Islam (1)" dalam www.islam-download.net (3 Desember 2008).

Yusoff , Zulkifli Haji Mohd \& Fikri Mahmud, "Gerakan Teroris dalam Masyarakat Islam: Analisis terhadap Gerakan J emaah Islamiyah (J I)", dalam http://fikrimahmud.tripod.com (3Desember 2008). 